\title{
A Cláusula de Eleição de Foro em Contratos Internacionais ${ }^{1}$
}

\author{
Marta Gonçalves da Silva Soares
}

\section{INTRODUÇÃO}

A negociação de qualquer contrato internacional ${ }^{2}$ implica não somente na abordagem e definição das cláusulas que reflitam as condições negociais, mas também as relativas à eleição de foro e lei aplicável ao contrato.

Apesar da relevância dos inúmeros temas que cercam a negociação e estipulação das cláusulas inseridas nos contratos internacionais, o presente trabalho restringir-seá à problemática da eleição de foro nestes contratos, enfatizando as limitações impostas à liberdade contratual pelo ordenamento jurídico pátrio.

É mister ressaltar, preliminarmente, que a prévia análise das disposições existentes nos ordenamentos jurídicos envolvidos pelo contrato internacional, visando a delimitação das diversas cláusulas contratuais, dentre as quais a de eleição de foro,

\footnotetext{
${ }^{1}$ Monografia apresentada no Curso de Especializaçāo (Pós-Graduação Latu Sensu) "O Novo Direito Internacional", organizado pelo Departamento de Direito Público e Filosofia do Direito, da Faculdade de Direito da Universidade Federal do Rio Grande do Sul, $1^{\circledR a}$ edição, 1999-2000, sob a coordenação da Professora Dra. Cláudia Lima Marques.

${ }^{2}$ Conforme ressalta BASSO, Maristela, in: Contratos Internacionais do Comércio. Porto Alegre: Livraria do Advogado, 1998, p. 17-18, não é fácil definir um contrato internacional, inexistindo uma única e uniforme conceituação do mesmo. Contudo, normalmente verifica-se, consoante ensinamentos de STRENGER, Irineu, in: Contratos Internacionais do Comércio. $3^{\text {a }}$ ed., São Paulo: LTr, 1998, p. 30, que os contratos internacionais se caracterizam pela sua "vinculação a um ou mais sistemas jurídicos estrangeiros, além de outros dados de estraneidade, como o domicílio, a nacionalidade, a lex voluntatis, a localização da sede, centro de principais atividades, e até a própria conceituação legal." ROVIRA, Suzan Lee Zaragoza, in: Estudo Comparativo sobre os Contratos Internacionais, Aspectos Jurídicos e Doutrinários. Contratos Internacionais, $2^{\mathrm{a}}$ ed. rev. e amp., São Paulo: Revista dos Tribunais, 1995, p. 52-53, esclarece, por sua vez, que são justamente estes elementos de estraneidade relativos à conclusão, capacidade das partes ou objeto, ligando o contrato de forma efetiva ou potencial a dois ou mais sistemas jurídicos, que caracterizam um contrato internacional, diferenciando-o daquele de direito interno.
} 
consiste, acima de tudo, em um elemento de segurança jurídica das partes ${ }^{3}$, as quais têm conhecimento de eventuais implicações ou argumentos a serem utilizados, quando de um litígio envolvendo o contrato celebrado.

Note-se que embora as partes tenham, a princípio, liberdade de escolha do foro para reger o contrato e existam vários foros competentes de diferentes países, o que acarreta o forum shopping decorrente da escolha daquele mais favorável, há normas que devem ser observadas e consideradas quando da negociação de um contrato na esfera do direito internacional.

É, portanto, de suma importância analisar as disposições contidas no ordenamento jurídico brasileiro, além da posição dos tribunais acerca do tema, a fim de verificar eventuais limitações que restrinjam ou afastem o disposto pelas partes no tocante ao foro eleito para proceder ao julgamento das controvérsias originárias do contrato internacional firmado pelas mesmas. Este consiste, em suma, do objeto do presente trabalho.

Em um primeiro momento, será apresentado um breve relato histórico acerca da aceitação das cláusulas de eleição de foro, além da diferenciação desta cláusula e daquela que elege a lei aplicável ao contrato.

Após uma breve abordagem histórica e delimitação conceitual, analisaremos a questão da liberdade contratual na estipulação das cláusulas de eleição de foro em contratos internacionais, bem como as limitações presentes no ordenamento jurídico pátrio. Também serão objeto de estudo, ainda que de forma sucinta, as disposições constantes do Protocolo de Buenos Aires, que rege o tema no âmbito do Mercosul.

O objetivo, portanto, é apresentar um estudo o qual aborde as diferentes circunstâncias que poderão ser consideradas pelo ordenamento jurídico pátrio para afastar ou não a atuação do juiz brasileiro em causas que versem sobre contratos com cláusulas de eleição de foro tanto aqui quanto em país estrangeiro.

Cumpre mencionar, outrossim, que o presente trabalho limitar-se-á à análise do tema em relação aos contratos internacionais firmados entre pessoas físicas e jurídicas de diferentes países, sem contemplar quaisquer hipóteses envolvendo Estados como partes contratantes e eventuais implicações decorrentes de imunidades de jurisdição.

Ressalte-se, por fim, que as constatações e conclusões a serem apresentadas têm por base não somente os doutrinadores pátrios, mas também alguns artigos de autores estrangeiros acerca do tema. A jurisprudência, por sua vez, não se restringe a nenhum tribunal nacional ou estrangeiro específico, sendo citada de forma exemplificativa toda vez que necessária para ilustrar o assunto abordado.

\footnotetext{
${ }^{3}$ Neste sentido, BORN, Gary B., in: International Civil Litigation in United States Courts. Third Edition. Den Haag, Holanda: Kluwer Law International. 1996, p. 372, menciona a decisão Scherk v. AlbertoCulver Co., 417 U.S. 506, 516 (1974) da Suprema Corte norte-americana em que foi ressaltada a importância da especificação da cláusula de eleição de foro nos contratos internacionais. No referido caso foi decidido que "a contractual provision specifying in advance the forum in which disputes shall be litigated and the law to be applied is... an almost indispensable precondition to achievement of the orderliness and predictability essential to any international business transaction."
} 


\section{A DELIMITAÇÃO DA CLÁUSULA DE ELEIÇÃO DE FORO}

\subsection{ABRANGÊNCIA}

Quando de um litígio envolvendo um contrato internacional, o juiz estatal deverá, preliminarmente, verificar se é competente para o julgamento do feito para, após, analisar qual a legislação (nacional ou estrangeira) que rege o caso concreto. Dependendo do país no qual o feito é julgado, a legislação aplicável ao contrato poderá ser diversa, por força das normas de direito internacional privado e elementos de conexão previstos no ordenamento jurídico daquele país no qual a ação foi ajuizada e está sendo julgada.

Uma questão está diretamente relacionada à outra, sendo, portanto, imprescindível, na esfera do direito internacional privado, analisar o conteúdo das cláusulas referentes à escolha da lei e do foro do contrato, pois apesar de distintas, devem ser discutidas e convencionadas de forma conjunta, tendo em vista que uma tem implicação direta na outra, em especial nos ordenamentos jurídicos que não admitem a liberdade de escolha da lei aplicável ao contrato, como ocorre no direito brasileiro.

Em decorrência da cláusula de eleição de foro, é estipulado o foro no qual serão apreciadas e julgadas eventuais controvérsias originárias do contrato. As partes podem, a princípio, livremente convencionarem esta cláusula, salvo eventuais limitaçóes existentes no ordenamento jurídico do foro eleito e também daquele das partes contratantes, o que será abordado na terceira parte deste trabalho.

Difere da cláusula de eleição da lei aplicável ao contrato, através da qual é convencionada a legislação a ser observada tanto pelas partes quanto pelo órgão julgador. Além da limitação imposta pela ordem pública, há ordenamentos que expressamente vedam a livre estipulação da lei aplicável ao contrato. Contudo, considerando que o objeto do presente estudo restringe-se às cláusulas de eleição de foro, limitamo-nos a salientar, em relação às cláusulas de eleição de lei, que o artigo 9º, caput, da Lei de Introdução ao Código Civil não contemplou, no direito pátrio, a autonomia da vontade como elemento de conexão, impossibilitando que as partes livremente estipulem qual a lei aplicável ao contrato internacional firmado pelas mesmas ${ }^{4}$.

Esta distinção é de suma importância, pois, conforme salienta Nadia de Araujo ${ }^{5}$, apesar da influência que uma cláusula exerce na outra, ambas não se confundem: "É preciso deixar bem claro que a cláusula de eleição de foro e de lei aplicável ao contrato não se confundem. Pode-se escolher um determinado foro para discutir os litígios advindos da relação contratual e naquele local utilizar-se a lei de um terceiro país no que diz respeito às regras

\footnotetext{
${ }^{4}$ Em relação à autonomia da vontade e cláusula de eleição de lei no ordenamento jurídico brasileiro, vide ARAUJO, Nadia de. Contratos Internacionais: autonomia da vontade, Mercosul e convenções internacionais. $2^{\mathrm{a}}$ edição revista e ampliada, Rio de Janeiro: Renovar, 2000.

${ }^{5}$ In: A autonomia da vontade nos contratos internacionais - direito brasileiro e países do Mercosul: Considerações sobre a necessidade de alterações no Direito Internacional Privado Obrigacional do Bloco. Palestra proferida no Curso de Especialização "O Novo Direito Internacional" promovido pela Universidade Federal do Rio Grande do Sul, 16.07.1999, p. 7.
} 
materiais concernentes ao contrato em questáo. No entanto, a redação e a escolha dessas cláusulas deve ser feita em conjunto, de modo que se o foro escolhido proibir a autonomia da vontade, a cláusula de lei aplicável poderá ser invalidada pelo juiz que estiver discutindo a questão em face de uma proibição da lei local. Desta forma, estão interligadas e as conseqüências de uma determinada escolha influi na outra cláusula."

Assim também já se posicionava Arnoldo Wald ${ }^{6}$ acerca do tema, ao ressaltar que embora as cláusulas de eleição de foro e de lei aplicável a um contrato sejam distintas, devem ser analisadas conjuntamente: "Os dois problemas, embora materialmente conexos, são distintos, importando a cláusula eletiva de foro na concessão de uma competência contratual à Justiça de determinada cidade ou de certo país, enquanto a escolha de lei estrangeira para firmar as conseqüências jurídicas do contrato se fundamenta no princípio da autonomia da vontade e estabelece o regime jurídico substantivo aplicável à relação jurídica. A primeira questáo é puramente processual e se apresenta tanto no plano nacional como internacional, sendo a segunda tipicamente de direito internacional privado."

Neste contexto, percebe-se a importância de ambas as cláusulas, as quais, na negociação de um contrato internacional, deverão ser expressamente convencionadas pelas partes e analisadas conjuntamente em face de eventuais implicações decorrentes das normas existentes no ordenamento jurídico do país, cujo foro é eleito pelas mesmas.

Como visto e consoante os ensinamentos de Eduardo Espínola, "quando se suscita alguma questão de direito internacional privado, o primeiro problema, que se apresenta, éo da autoridade competente para o exame e decisão da controvérsia" "e superada a questão da competência do órgão julgador deverá este verificar qual a legislação aplicável ao caso. A primeira questão a ser abordada é, portanto, a da competência e validade da cláusula de eleição de foro para que, após, possa ser analisado o disposto pelas partes no tocante à lei aplicável ao contrato firmado pelas mesmas.

A análise prévia destas questões evita, assim, que, quando do julgamento de uma causa envolvendo um contrato internacional, o juiz estatal, com base na lex fori, entenda que não é competente para o julgamento do feito, ou, tendo competência concorrente, afaste o disposto contratualmente pelas partes no tocante ao foro eleito, e, ainda, invalide

\footnotetext{
${ }^{6}$ In: Validade das Convenções sobre foro do contrato. Estudos e pareceres de Direito Comercial. São Paulo: Revista dos Tribunais, 1972, p. 261.

7 In: A Lei de Introdução ao Código Civil Brasileiro. Volume III, 3르 ed. Rio de Janeiro: Renovar, 1999, p. 184-185.
} 
cláusula eletiva de lei, eis que diversa daquela prevista na legislação pátria ou consistente de matéria insuscetível de ser livremente pactuada pelas partes ${ }^{8}$.

O tema, portanto, é de suma importância e deverá ser cuidadosamente analisado mesmo que as partes convencionem e insiram uma cláusula de arbitragem no contrato firmado pelas mesmas.

Note-se que muito embora atualmente se verifique uma tendência de ser estipulada pelas partes uma cláusula de arbitragem, isto não obsta nem exclui, na vigência da Lei de Arbitragem Brasileira - Lei 9.307, de 23 de Setembro de 1996 -, a necessidade de inclusão da cláusula de eleição do foro competente para julgar eventuais questões que necessitem da intervenção do Poder Judiciário, sendo que "a inserção dessa disposição sobre foro e lei aplicáveis à arbitragem, se encontra, na verdade, dentre aqueles acréscimos à cláusula arbitral tradicional sugeridos pelo bom senso no âmbito das negociaçōes?."

Com efeito, a Lei Brasileira de Arbitragem não afasta a participação do Poder Judiciário, conforme se verifica em relação aos artigos $6^{\circ}$, parágrafo único e $7^{\circ}, 11$, parágrafo único, $13, \S 2^{\circ}, 16, \S 2^{\circ}$, em confronto com o artigo 20 , $\S \S 1^{\circ}$ e $2^{\circ}$, 22 , $\S \S 2^{\circ}$ e $4^{\circ}, 25,33$, caput e parágrafos, e $35 \mathrm{e}$, portanto, eventuais questóes relacionadas com a arbitragem poderão efetivamente ser apreciadas e julgadas pelo juiz estatal. Desta forma, o Poder Judiciário pode ser acionado para fixar honorários dos árbitros, julgar pedido de nulidade, invalidade ou ineficácia de convenção arbitral, determinar medidas coercitivas ou cautelares, quando necessárias, dentre outras, sendo, assim, prudente, as partes indicarem, desde já, o foro competente para julgamento das açōes judiciais relativas à arbitragem.

Importante frisar que caso as partes não estipulem a cláusula de eleição de foro no contrato, será competente o juiz que teria conhecido da demanda se não existisse convenção arbitral, o que não guarda qualquer relação com o lugar da arbitragem. Desta forma, o fato de uma questão ser julgada por um tribunal arbitral localizado em

${ }^{8}$ BORN, Gary B. In: International Civil Litigation in United States Courts. Third Edition. Den Haag, Holanda: Kluwer Law International. 1996, p. 440-445 transcreve decisão da United States District Court for the District of Puerto Rico, na qual fica patente a necessidade de previamente analisar o disposto na legislação dos paises das partes contratantes, em especial no tocante à eleição de foro e lei aplicável a um contrato. No caso em tela, a empresa americana Royal Bed and Spring Co. ajuizou ação, em Porto Rico, por quebra de contrato de distribuição mercantil firmado em Curitiba, com a empresa brasileira Famossul Indústria e Comércio de Móveis Ltda.. O autor da ação postulou indenização por quebra de contrato com base na legislação de Porto Rico aplicável aos contratos de distribuição naquele país. As partes haviam previamente estabelecido que o Brasil seria o foro competente para o julgamento de eventuais controvérsias, tendo a Corte Americana sustentado a validade desta cláusula por ser o foro mais conveniente para o julgamento do feito. Contudo, caso o entendimento tivesse sido diverso, a empresa brasileira estaria sujeita às normas que regulam os contratos de distribuição em Porto Rico e poderia ter sido eventualmente condenada naquele país. Sendo a ação julgada no Brasil e tendo o contrato sido aqui firmado, provavelmente a empresa de Porto Rico não teria êxito na ação, eis que inexistente, a época, norma expressa regulando os contratos de distribuição mercantil no ordenamento jurídico brasileiro (o Novo Civil Brasileiro regula, no entanto, expressamente, a matéria). Verifica-se, assim, que dependendo do pais no qual a ação fosse julgada, o resultado final da mesma poderia ser diverso, favorecendo uma ou outra parte contratante.

9 MELLO, Marcelo Oliveira e ANDRADE, Carlos Cesar Borromeu de. In: A Arbitragem nos Contratos Comerciais e Petroliferos Internacionais. A Arbitragem na Era da Globalização. Coordenador: José Maria Rossani Garcez, Rio de Janeiro: Forense, 1997, p. 154. 
determinado país não implica necessariamente que este seja o foro competente para julgamento das questões submetidas à apreciação do Poder Judiciário. O lugar da arbitragem não determina, portanto, na sistemática da Lei $9.307 / 96$, o foro competente estatal para julgamento de eventuais controvérsias.

Carlos Alberto Carmona ${ }^{10}$ ressalta que a sistemática prevista pelo legislador pátrio é diversa da estabelecida na legislação italiana, na qual a sede da arbitragem é um elemento de conexão relevante para a fixação da competência do juiz togado para a prática de atos relacionados ao juízo arbitral: "O estabelecimento da sede da arbitragem nâo tem relevância no que se refere à fixação da competência do juiz estatal para as demandas ligadas ao juízo arbitral. Ao contrário dos italianos, que preconizam ser a sede elemento de conexão relevante para a fixação de competência do juiz togado para a prática de atos que interessam ao juízo arbitral (o juiz do local onde esteja situada a sede da arbitragem será competente, inclusive, para o depósito do laudo, quando condenatório), olegislador pátrio adotou outro critério (histórico, aliás), prevendo que será competente para praticar os atos ligados à arbitragem (antes, durante e depois: para a demanda de que trata o art. $7{ }^{\circ}$, para as providências a que se refere $o$ art. $22, \$ 4^{\circ}$, e para a demanda de anulação de que cuida o art. 32) ojuiz que dela teria conhecido se não existisse convenção arbitral (ou seja, o juiz natural), tudo sem prejuízo de elegerem as partes foro para a eventualidade de terem de recorrer ao PoderJudiciário."

Da mesma forma como ocorre no direito italiano, Peter $\mathrm{Nygh}^{11}$ ressalta que esta posição é também adotada pelo direito inglês, segundo o qual "the traditional view, at least among English lawyers, is that the arbitration has a forum, like any other national court, and that it is the situs of the arbitration."

Percebe-se, novamente, a necessidade de verificar as normas existentes nos ordenamentos jurídicos com alguma relação com o contrato firmado entre as partes, além da legislação em vigor no país sede da arbitragem e das regras da Câmara de arbitragem, caso escolhida pelas partes, pois é possível que, dependendo da análise destes fatores, seja também recomendável inserir, assim como ocorre na sistemática da Lei de Arbitragem Brasileira 9.307/96, cláusula de eleição de foro para o julgamento das questóes ligadas à demanda referente à arbitragem.

Marcelo Oliveira Mello e Carlos Cesar Borromeu de Andrade ${ }^{12}$ recomendam, ainda, a fim de escolher o foro para solução das controvérsias relacionadas à arbitragem, seja analisado o ordenamento jurídico do país cuja lei e foro melhor se adaptem à solução de possíveis conflitos, considerando a possibilidade de execução forçada de uma sentença arbitral, além da garantia de parâmetros mínimos para eventual questionamento judicial da sentença arbitral.

\footnotetext{
${ }^{10}$ In: Arbitragem e processo: um comentário à Lei 9.307/96. São Paulo: Malheiros Ed., 1998, p. 143.

11 In: Choice of Forum and Law in International Commercial Arbitration. Forum Internationale $\mathrm{n}^{\circ} 24$, Junho de 1997. Palestra proferida no Forum Internacional em Haia, em $1^{\circ}$ de Novembro de 1996. Holanda: Kluwer Law International, 1997, p. 03.

12 In: A Arbitragem nos Contratos Comerciais e Petrolíferos Internacionais. A Arbitragem na Era da Globalização. Coordenador: José Maria Rossani Garcez, Rio de Janeiro: Forense, 1997, p. 154-155.
} 
Eventual cláusula de arbitragem não exclui, portanto, a prévia análise, negociação e inclusão de cláusula de eleição do foro no contrato firmado entre as partes, pois existem questóes relacionadas à arbitragem que demandam a intervenção do Poder Judiciário e, como visto, o lugar da arbitragem não é necessariamente elemento indicativo do foro competente.

\subsection{EVOLUÇÃOHISTÓRICA}

Embora a cláusula de eleição de foro seja amplamente aceita, é importante ressaltar que nem sempre este foi o posicionamento adotado pelos tribunais, tendo a abordagem desta questão evoluído até alcançar o status atual de aceitação, ressalvadas eventuais limitaçōes existentes, as quais serão objeto de análise na terceira parte deste trabalho.

Moacir Amaral ${ }^{13}$ ressalta que o forum contractus, ou seja, o foro da convenção das partes, consiste de prática existente desde o direito romano, tendo sua utilização tomado grande impulso na Idade Média, em decorrência do intenso desenvolvimento do comércio entre diferentes povos de distintas regióes.

Apesar de sustentada por Moacir Amaral a admissibilidade da eleição de foro desde o direito romano, Jacob Dolinger ${ }^{14}$, por sua vez, ressalta que verificava-se antigamente uma repulsa dos tribunais em relação à liberdade contratual para a escolha do foro, tendo a Cour de Cassation decidido em 1843 que a competência dos tribunais era "questão de ordem pública que não podia ser excluída por acordo."

No Brasil, apesar de atualmente a cláusula de eleição de foro ser amplamente aceita no ordenamento jurídico pátrio, inclusive existindo Súmula ${ }^{15}$ do Supremo Tribunal Federal sustentando a validade da mesma, verifica-se que, inicialmente, também existiu relativa oposição à mesma.

Neste sentido, Jacob Dolinger ${ }^{16}$ menciona acórdão do Supremo Tribunal Federal Brasileiro de 1906 (Dr. Coelho Rodrigues v. New York Life Insurance), no qual este decidiu que "uma sociedade estrangeira que opera no Brasil fica submetida, nas operaçóes realizadas no país, à competência dos tribunais brasileiros, não podendo contornar esta regra, que é de ordem pública, através de convençōes que atribuam competência aos tribunais do local da sua sede social no estrangeiro."

A jurisprudência pacífica do Supremo Tribunal Federal, no início do século $\mathrm{XX}$, era justamente no sentido de que não poderiam ser homologadas no Brasil eventuais

\footnotetext{
${ }^{13}$ In: Primeiras Linhas de Direito Processual Civil. $1^{19}$ volume. $10^{\mathfrak{a}}$ ed. Atualizada. São Paulo: Ed. Saraiva, 1983, p. 24.

14 In: A evolução da ordem pública no direito internacional privado. Tese. Rio de Janeiro, 1979, p. 214.

${ }^{15}$ Dispõe a Súmula 335, do Supremo Tribunal Federal que "é válida a cláusula de eleição de foro para os processos oriundos do contrato."

${ }^{16}$ In: A evolução da ordem pública no direito internacional privado. Tese. Rio de Janeiro, 1979, p. 214.
} 
decisões proferidas por tribunais estrangeiros, quando aqui fosse residente ou domiciliado o réu ${ }^{17}$. Este posicionamento foi reforçado pela antiga Lei de Introdução ao Código Civil (Lei $\mathrm{n}^{\mathrm{0}} 3.071 / 16$ ), a qual, em seu artigo 15, atualmente revogado pelo DecretoLei no 4.657/42, determinava que "rege a competência, a forma do processo e os meios de defesa a lei do lugar, onde se mover a ação; sendo competentes sempre os tribunais brasileiros nas demandas contra as pessoas domiciliadas ou residentes no Brasil, por obrigaçóes contraídas ou responsabilidades assumidas neste ou noutro país."

Constata-se que, em face do advérbio "sempre" contido no já revogado artigo 15 da antiga Lei de Introdução ao Código Civil, não era permitido, na vigência desta, ao réu, domiciliado no Brasil, renunciar, através de cláusula contratual, à competência do foro brasileiro. Atualmente esta restrição refere-se unicamente às açôes referentes à imóveis situados no Brasil, por força do disposto no artigo 12 , $§ 1$, da Lei de Introdução do Código Civil e às matérias elencadas no artigo 89 do Código de Processo Civil Brasileiro, as quais apresentam hipóteses de competência absoluta da justiça brasileira.

Arnoldo Wald ${ }^{18}$, por sua vez, salienta que, no âmbito do direito interno, por algum tempo os tribunais pátrios também entenderam que não deveria prevalecer a convenção entre as partes relativa à eleição de um foro do contrato, tendo em vista o silêncio do Código de Processo Civil Brasileiro de 1939 sobre o tema.

Apesar desta omissão, destacou-se o posicionamento na doutrina e jurisprudências pátrias ${ }^{19}$, segundo o qual prevaleceria, na vigência do Código de Processo Civil de 1939, o disposto no artigo 42 do Código Civil Brasileiro ${ }^{20}$, tendo o Código de 1973 reforçado esta posição, estabelecendo, expressamente, em seu artigo 111, que as partes "podem modificar a competência em razáo do valor e do território, elegendo foro onde seráo propostas as açōes oriundas de direitos e obrigaçóes."

\footnotetext{
${ }_{17}$ Neste sentido, OCTAVIO, Rodrigo, in: Manual do Código Civil Brasileiro, volume 1, Parte Segunda, Direito Internacional Privado, arts. 8 a 21, Rio de Janeiro: Livraria Jacintho, 1932, 373, transcreve parecer do Ministro Pires e Albuquerque, então Procurador Geral da República, no processo de homologação $n^{\circ} 873$, que reflete a posicionamento da época, segundo o qual os pedidos de homologação eram denegados, tendo em vista que, residindo o demandado no Brasil, o foro brasileiro era o único competente para o conhecimento da causa: "Segundo o considerou o Egrégio Tribunal na homologação n. 666, julgada em 22 de Maio de 1912: Reconhecem os escritores de direito internacional, que, ainda quando haja leis expressas que declarem os Tribunais de um País competentes para processar e julgar ações intentadas contra estrangeiros, não é possivel executar as sentenças proferidas por tais Justiças no País do réu. O art. 14 do Código Civil Francês, nota PILET, faculta julgamentos que nunca se executam no estrangeiro; proferidos pelos Tribunais franceses contra estrangeiros que não possuem bens na França; razões de ordem pública se opõem a que tais sentenças sejam executadas nos países onde residem os réus - (Princípios de Direito Internacional Privado). O mesmo ensina DESPAGNET no seu Precis de Droit International Privé. Essa doutrina tem sido invariavelmente seguida como se pode ver entre outras nas homologaçōes números 676, de 1914, e 825, de 1925, e constitui jurisprudência pacífica."

${ }_{18}^{18}$ In: Validade das Convenções sobre Foro do Contrato. Estudos e Pareceres de Direito Comercial. $1^{\mathrm{a}}$ série. São Paulo: Ed. Revista dos Tribunais, 1972, p. 261-266.

${ }^{19}$ Neste sentido, vide os comentários de VALLADÃO, Haroldo. O Contrato Internacional. Revista Forense $n^{\circ}$ 269, Ano 76, Janeiro-Março de 1980, p. 04.

${ }^{20} \mathrm{O}$ artigo 42 do Código Civil Brasileiro assegura às partes contratantes a possibilidade de "especificaro domicilio onde se exercitem e cumpram os direitos e obrigações deles resultantes."
} 
Assim, segundo a posição atual a eleição do foro é amplamente aceita, tendo o Supremo Tribunal Federal Brasileiro, conforme demonstrado por Arnoldo Wald ${ }^{21}$, firmado, a partir de 1951, sua posição no sentido de admitir a validade da cláusula de eleição do foro, culminando, em 16.12.1963, com a Súmula 335 deste órgáo jurisdicional.

Da mesma forma e a título meramente ilustrativo para análise do tema na esfera internacional, ressaltamos que as cortes norte-americanas, historicamente, também sempre foram contrárias às cláusula de eleição de foro em relação aos contratos internacionais e também de direito interno ${ }^{22}$. Conforme menciona Gary B. Born ${ }^{23}$, somente a partir do final da década de quarenta, as cortes norte-americanas começaram a abandonar a regra tradicional de que as cláusulas de eleição de foro seriam por si só inexeqüíveis.

Nos Estados Unidos, em 1955 verifica-se uma decisão ${ }^{24}$, na qual a cláusula de eleição de foro não foi rejeitada, tendo em vista a corte local ter entendido que a mesma seria razoável. Em 1964, a Corte Suprema dos Estados Unidos, ao analisar a questão da cláusula de eleição de foro, entendeu que "it is settled that parties to a contract may agree in advance to submit to the jurisdiction of a given court, to permit notice to be served by the opposing party, or even to waive notice altogether", tendo sido, logo após, aprovado em 1968 o Model Choice of Forum Act regulando a matéria.

As disposiçōes contidas no Model Choice of Forum Act foram a base para a nova redação da Seção 80 do Restatement (Second) Conflict of Laws, o qual permitiu a eleição de foro pelas partes, desde que este fosse justo ou razoável ${ }^{25}$.

Gary B. Born ${ }^{26}$ refere, ainda, que o leading case americano relativo ao tema da eleição do foro foi julgado um ano após o Restatement Conflict of Laws. No famoso caso The Bremen v. Zapata Off-Shore $\mathrm{Co}^{27}$ foi decidido que as cláusulas de eleição de foro "are prima facie valid and should be enforced unless enforcement is shown by the resisting

\footnotetext{
${ }^{21}$ In: Validade das Convenções sobre Foro do Contrato. Estudos e Pareceres de Direito Comercial. $1^{\underline{a}}$ série. São Paulo: Ed. Revista dos Tribunais, 1972, p. 261-266.

${ }^{22}$ Neste sentido é o voto do Chief Justice Burger, no caso The Bremen v. Zapata Off-Shore Co., 407 U.S. 1 (1972), citado por BORN, Gary B., In: International Civil Litigation in United States Courts, Third Edition. Den Haag, Holada: Kluwer Law International, 1996, p. 385, ao sustentar que "forum selection clauses have historically not been favored by American Courts. Many courts, federal and state, have declined to enforce such clauses on the ground that they were 'contrary to public policy', or that their effect was to 'oust the jurisdiction' of the court. Although this view apparently still has considerable acceptance, other courts are tending to adopt a more a more hospitable attitude toward forum selection clauses."

${ }^{23}$ In: International Civil Litigation in United States Courts. Third Edition. Den Haag, Holanda: Kluwer Law International. 1996.

${ }^{24}$ A referida decisão é Wm. H. Muller \& Co. v. Swedish American Line Ltd., 224 F.2d 806, Second Circuit, cert. Denied, 350 U.S. 903 (1955) citada por BORN, Gary B. In: International Civil Litigation. Third Edition. Den Haag, Holand: Kluwer Law International. 1996, p. 374.

${ }^{25}$ Segundo a Seção 80 do Restatement (Second) Conflict of Laws, "the parties' agreement as to the place of the action cannot oust a state of judicial jurisdiction, but such an agreement will be given effect unless it is unfair or unreasonable".

${ }^{26}$ In: International Civil Litigation in United States Courts. Third Edition. Den Haag, Holanda: Kluwer Law International. 1996, p. 377.

${ }^{27} 407$ U.S. 1 (1972), the Unites States Court of Appeals for the Fifth Circuit.
} 
party to be 'unreasonable' under the circumstances." Mais recentemente, no ano de 1991, no caso Carnival Cruise Lines, Inc. v. Shute ${ }^{28}$, foi considerada válida a cláusula de eleição de foro contida em bilhete impresso de passagem de navio, sob o argumento de que seria razoável ${ }^{29}$.

Verifica-se, portanto, a partir do célebre leading case Bremen v. Zapata uma aceitação cada vez maior das cláusulas de eleição de foro por parte não somente das cortes norte-americanas ${ }^{30}$, mas também da legislação daquele país, citando-se, exemplificativamente, a New York General Obligation Law $\$ 5-1402^{31}$, segundo a qual qualquer ação envolvendo uma empresa estrangeira poderá ser julgada em Nova York, desde que o litígio decorra de uma obrigação contratual de mais de US\$1.000.000,00 (um milhão de dólares americanos) e as partes tenham expressamente convencionado que lá seria o foro competente para o julgamento da controvérsia.

A tendência, portanto, não somente no direito brasileiro como nos demais países é a aceitação da cláusula de eleição de foro, ressalvadas algumas limitações como abordaremos no tópico a seguir.

\section{A ELEIÇÃO DE FORO E SUAS LIMITAÇÕES NO} ORDENAMENTOJURÍDICOPÁTRIO

Conforme anteriormente mencionado, a cláusula de eleição de foro tem ampla aceitação no direito pátrio, inclusive existindo Súmula do Supremo Tribunal Federal sustentando a validade da mesma.

\footnotetext{
${ }^{28} 499$ U.S. 585 (1991), the United States Court of Appeals for the Ninth Circuit.

${ }^{29} \dot{E}$ interessante transcrever parte da decisão em tela, a fim de demonstrar a fundamentação utilizada para atestar a razoabilidade da cláusula de eleição de foro: "In evaluating the reasonableness of the forum clause at issue in this case, we must refine the analysis of Bremen to account for the realities of form passage contracts. As an initial matter, we do not adopt the Court of Appeals' determination that a non-negotiated forum selection clause in a form ticket contract is never enforceable simply because it is not the subject of bargaining. Including a reasonable forum clause in a form contract of this kind well may be permissible for several reasons: First, a cruise line has a special interest in limiting the fora in which it potentially could be subject to suit. Because a cruise ship typically carries passengers from may locales, it is not unlikely that a mishap on a cruise could subject the cruise line to litigation in several different fora. Additionally, a clause establishing ex ante the forum for dispute resolution has the salutary effect of dispelling any confusion about where time and expense of pretrial motions to determine the correct forum, and conserving judicial resources that otherwise would be devoted to deciding those motions. Finally, it stands to reason that passengers would purchase tickets containing a forum clause that at issue in this case benefit in the form of reduced fares reflecting the savings that the cruise line enjoys by limiting the fora in which it may be sued".

${ }^{30}$ Vide os comentários de MAIER, Harold G., In: The U.S. Supreme Court and the "user-friendly" forum selection clause: the effect of the Carnival Cruise Lines on Intemational Contracts. International Dispute Resolution: The regulation of forum selection (Fourteenth Sokol Colloquium). Coordenador: J.L. Godsmith. Irvinton, New York: Transnational Publishers, Inc., 1997, p. 53 acerca das cláusulas de eleição de foro e a evolução jurisprudencial norte-americana referente às mesmas.

${ }^{31}$ Conforme esclarece BORN, Gary B., In: International Civil Litigation in United States Courts. Third Edition. Den Haag, Holanda: Kluwer Law International. 1996, p. 381, a New York Obligation Law § 5-1402 dispõe que "any person may maintain an action or proceeding against a foreign corporation (...) arising out of a contractual obligation for more than \$1 million, where the parties' agreement (...) contains a provision (...) whereby such foreign corporation (...) agrees to submit to the jurisdiction of the courts of this state."
} 
Não obstante esta ampla aceitação e expressa previsão legal no nosso direito interno (artigo 111 do Código de Processo Civil Brasileiro), existem uma série de limitações em relação à eleição do foro de um contrato que devem ser observadas e consideradas pelas partes contratantes na esfera do direito internacional.

Neste capítulo, abordaremos as limitações existentes na legislação pátria, bem como as normas vigentes no Mercosul acerca do tema, destacando, ainda, a aplicação e utilização do princípio da efetividade para afastar a atuação do juiz estatal nacional.

\subsection{ORDEM PÚBLICA}

A primeira grande limitação à liberdade das partes para fixação das cláusulas de eleição de foro em contratos internacionais consiste na ordem pública.

Dispõe expressamente o artigo 17 da Lei de Introdução do Código Civil Brasileiro que "as leis, atos e sentenças de outro País, bem como quaisquer declarações de vontade, não terão eficácia no Brasil, quando ofenderem a soberania nacional, a ordem pública e os bons costumes."

Assim sendo, mesmo que eventualmente competente a autoridade judiciária do foro estrangeiro eleito pelas partes, este somente será válido se inexistir fraude à lei e violação à ordem pública ${ }^{32}$.

Indaga-se, no entanto, no que consistiria a ordem pública. Rodrigo Octavio ${ }^{33}$, em 1932, já ressaltava a dificuldade de definir o conceito de ordem pública, concluindo que "a definição de ordem pública permanece, pois no indeterminado do seu conceito, sendo que o critério mais geral e simples (...) é o que liga o princípio da ordem pública ao interesse geral da sociedade, com abstração do interesse privado do indivíduo."

Segundo Jacob Dolinger ${ }^{34}$, o conceito de ordem pública seria de difícil delimitação, consistindo "daqueles fenômenos que melhor se compreendem como sentimento do que com a razão", sendo seus objetivos claros: "A ordem pública no direito interno visa manter o equilibrio das forças que se debatem no processo social, e, se via de regra a autoridade administrativa não pode atentar contra as liberdades individuais, necessidades fundamentais da sociedade podem eventualmente suspender esta interdição, se as partes contratantes são livres para exercer soberanamente suas vontades, novamente as necessidades sociais tem a força de cercear esta autonomia. Da mesma forma no Direito Internacional Privado a ordem

32 O Supremo Tribunal Federal, no tocante à admissibilidade da eleição de foro estrangeiro, decidiu, em 24.01.1957, que "o direito brasileiro reconhece o foro contratual, salvo quando existir impedimento de ordem pública" (RE 30.636, Primeira Turma, Rel. Min. Candido Motta, Ementário vol. 298, p. 393). Neste mesmo sentido, vide as decisões do Supremo Tribunal Federal, referentes às Sentenças Estrangeiras de $n^{\circ}$ 993, de Portugal, RT 136/824; no 1.080, DJ 09.08.1949, p. 2035 e de no 1.095, DJ 29.04 .1949 , p. 3.003/4 referidas por FRANCESCHINI, José Inácio Gonzaga. In: A Lei e o Foro de Eleição em tema de Contratos Internacionais, Contratos Internacionais, Coord. João Grandino Rodas, $2^{\mathrm{a}}$ ed., São Paulo: Editora Revista dos Tribunais, 1995, p. 126.

${ }^{33}$ In: Manual do Código Civil Brasileiro, volume 1, Parte Segunda, Direito Internacional Privado, arts. 8 a 21, Rio de Janeiro: Livraria Jacintho, 1932, 421-424.

${ }^{34}$ In: A evolução da ordem pública no direito internacional privado. Tese. Rio de Janeiro. 1979, p. XIII. 
pública visa evitar que a aplicação de leis estrangeiras, conforme o comando das múltiplas regras de conexão, cause traumatismo na sociedade nacional. O limite do universalismo imanente a toda ciência jurídica internacional reside no ponto em que a aplicação da lei estrangeira venha a chocar filosófica, sociológica, econômica, jurídica ou politicamente o foro processualmente competente para dirimir o conflito de interesses ou a declaração de direitos."

Em face da inexistência de uma definição legal de ordem pública, recomendase, a análise tanto das normas contidas no ordenamento jurídico, quanto da doutrina e da jurisprudência acerca do tema ${ }^{35}$, a fim de verificar se a questão, naquele momento histórico, viola ou não a ordem pública.

A ordem pública, consiste, assim, em uma limitação à liberdade das partes, as quais não poderão violá-la, sob pena de acarretar a nulidade e inobservância da cláusula de eleição de foro pactuada pelas mesmas.

\subsection{COMPETENNCLA INTERNACIONAL}

Além de eventual violação à ordem pública brasileira, cumpre ressaltar a necessidade de existir alguma relação do contrato e o foro eleito pelas partes contratantes. Exige-se, assim, que "o foro escolhido tenha alguma relação, ou uma relação relevante com o contrato e que a escolha não tenha decorrido de tentativa de fraude à lei. ${ }^{36 \text { " }}$

Neste sentido, José Inácio Gonzaga Franceschini ${ }^{37}$ sustenta que a liberdade contratual em matéria de eleição de foro brasileiro somente pode ser exercida quando o foro eleito for admitido pelo Direito Processual Brasileiro, ou seja, "quando presente

${ }^{35} \mathrm{O}$ Supremo Tribunal Federal manifestou-se acerca da violação à ordem pública em mais de uma ocasião, já tendo decidido, por exemplo, que "tratando-se de causa para a qual a justiça brasileira tem competência concorrente (relativa) (artigo 88 do CPC) e não absoluta (artigo 89), seu ajuizamento perante a justiça inglesa não fere a ordem pública nacional", além de que "a duplicidade de cartas rogatórias não configura violação à ordem pública, no Brasil, revestidas dos requisitos legais" (STF, AGRCR 5.815, Tribunal Pleno, Rel. Min. Sydney Sanchez, j. 20.12.1992). Neste mesmo sentido, decidiu que "tratandose de competência relativa da Justiça brasileira para demanda, o STF tem decidido que nada impede o curso da carta rogatória, por não atentar contra a ordem pública ou a soberania nacional" (AgRg na CR 4.964-1, Tribunal Pleno, Rel. Min. Néri da Silveira, j. 22.03.1991, DJU 16.08.1991, in RT 677/241). Da mesma forma decidiu que "não é admissível no Brasil a citação do réu pela forma inglesa do affidavit, pois, no tocante a forma do ato de procedimento, o direito brasileiro impõe que se observe a que é prevista no seu texto (art. 12, parágrafo $2^{\circ}$, da Lei de Introdução do Código Civil Brasileiro." (STF, AGRSE $n^{\circ}$ 2.671, Tribunal Pleno, Rel. Min. Antônio Neder, unânime, j. 04.06.1980, DJ 01.07.1980, p. 4943) e que “o Supremo já firmou entendimento no sentido de que o sistema do júri civil, adotado pela lei americana, não fere o princípio de ordem pública no Brasil" (STF, SEC no 4.415, Tribunal Pleno, Rel. Min. Francisco Rezek, j. 11.12.1996, DJ 03.04.1998, p. 07). Contudo, o Tribunal de Alçada do Estado do Rio de Janeiro (I TARJ, RT 589/221) já decidiu que "ofende a ordem pública a eleição, em contrato impresso de natureza unilateral e adesivo, da competência da Justiça de País estrangeiro, com exclusão da brasileira, em relação a contratos exeqüíveis no Brasil, a teor do artigo $9^{\circ}$ da Lei de Introdução ao Código Civil", conforme ementa a seguir transcrita: "Competência internacional - Transporte marítimo - Contrato de Adesão - Foro de eleição considerando competente Justiça do País estrangeiro- Contrato para ser cumprido no Brasil - Cláusula sem validade - Aplicação do artigo $9^{\circ}$ da LICC."

${ }^{36}$ In: BAPTISTA, Luiz Olavo. Contratos Internacionais. Revista Forense, volume 270, ano 76, junho de 1980, p.95.

${ }^{37}$ In: A lei e o foro de eleição em contratos internacionais. Contratos Internacionais. $2^{\mathrm{a}}$ ed., revista e ampliada, Coordenador João Grandino Rodas, São Paulo: Revista dos Tribunais, 1995, p. 91-145. 
ao menos um dos critérios ou elementos determinadones de jurisdição competente conhecidos pela ordem jurídica interna brasileira (ius fori)." Assim, a princípio, não poderia ser eleito, através de cláusula em contrato internacional, foro no Brasil, acaso não previsto dentro das hipóteses de competência internacional brasileira asseguradas na legislação pátria.

Botelho de Mesquita ${ }^{38}$ esclarece que as partes não criam a competência internacional, mas simplesmente se servem desta competência já criada antes por ato soberano do Estado, excluindo, através da cláusula de eleição de foro, a atuação de um dos dois juízes competentes - nacional e estrangeiro - para o julgamento do feito.

Assim sendo, devem ser consideradas as normas existentes no ordenamento pátrio que disciplinam a competência judiciária internacional, as quais estão previstas nos artigos 88 e 89 do Código de Processo Civil Brasileiro e também no artigo 12 da Lei de Introdução do Código Civil Brasileiro, com o escopo de verificar a existência de qualquer um dos elementos de conveniência de foro conhecidos pela legislação brasileira e a conseqüente possibilidade de eleição da justiça brasileira para o julgamento das controvérsias originárias de um contrato internacional, bem como as hipóteses nas quais somente esta, de forma exclusiva, pode conhecer da matéria.

Procederemos, desta forma, à análise das normas contidas na legislação pátria, a fim de delimitar a liberdade das partes, no que tange à estipulação de cláusula eletiva de foro em contrato internacional.

\subsubsection{COMPETÊNCIA RELATIVA}

Ainda que ambos os artigos 88 e 89 do Código de Processo Civil Brasileiro disciplinem o tema da competência internacional, a cláusula de eleição de foro somente é possível nos casos de competência relativa ou concorrente previstas no referido artigo 88 , tendo em vista que o artigo 89 disciplina as hipóteses de competência absoluta.

Cumpre, assim, abordar as hipóteses de competência internacional relativa previstas no ordenamento jurídico pátrio e as quais são contidas no artigo 88 do Código de Processo Civil Brasileiro, segundo o qual é competente a autoridade judiciária brasileira quando "(i) o réu, qualquer que seja a sua nacionalidade, estiver domiciliado no Brasil; (ii) no Brasil tiver de ser cumprida a obrigação e (iiii) a ação se originar de fato ocorrido ou de ato praticado no Brasil", reputando como domiciliado no Brasil para of fim do disposto no item (i) a pessoa jurídica estrangeira que aqui tiver agência, filial ou sucursal.

Considerando o disposto no referido artigo do Código de Processo Civil Brasileiro, os elementos de conveniência de foro indicativos da competência internacional da justiça brasileira são o domicílio, o local do cumprimento da obrigação, o local da ocorrência do fato que gerou a obrigação e a localização no país de agência, filial ou sucursal da pessoa jurídica estrangeira.

${ }^{38}$ In: Da Competência Internacional e dos Principios que a Informam. Revista de Processo ํㅜ 50, Ano XIII, Abril-Junho de 1988, p. 56-57. 
Assim, somente se presentes um destes elementos de conveniência é possível estipular, por acordo das partes, a justiça brasileira como o foro competente para julgamento das controvérsias originárias do contrato internacional firmado entre as mesmas. Caso estes elementos de conveniência sejam inexistentes no caso em concreto, a justiça brasileira, a princípio, é incompetente para o julgamento do feito, mesmo que seja indicada livremente pelas partes na cláusula de eleição de foro convencionada pelas mesmas ${ }^{39}$, pois conforme esclarecido por José Inácio Gonzaga Franceschini ${ }^{40}$, "a vontade de particulares não modifica ou cria jurisdição ou competência, estas já preexistemà manifestação privada." Assim, não cabe às partes atribuir a competência a um determinado país que não a possui; pelo contrário, pode-se, através de cláusula contratual, indicar um dentre os vários foros competentes para o julgamento do feito. A regra, no entanto, pode eventualmente comportar exceçōes, conforme se verificará ao analisarmos a questão do princípio da efetividade.

Impõe-se, portanto, analisar cada um destes elementos de conveniência previstos no ordenamento jurídico pátrio - artigo 88 do Código de Processo Civil -, a fim de delimitar as hipóteses nas quais as partes poderão livremente indicar, através de cláusula contratual, o Brasil como o foro para julgamento das controvérsias.

Note-se que o Código de Processo Civil refere-se unicamente ao domicílio e para definição do mesmo é preciso analisar as disposições contidas nos artigos 31 e 42 do Código Civil Brasileiro. Nada mais lógico do que acionar o réu no seu domicílio, independentemente de sua nacionalidade, circunstância esta que facilita a defesa do mesmo e a posterior execução do julgado ${ }^{41}$. Esclareça-se que, em relação à nacionalidade, tendo em vista que não incluída entre as hipóteses de competência ratione loci, somente será considerada como elemento indicativo da competência da justiça brasileira ou estrangeira quando ambas as partes contratantes forem de países ratificantes do Código

\footnotetext{
${ }^{39} \mathrm{Em}$ relação há necessidade de que esteja presente um dos elementos de conveniência previstos no ordenamento juridico pátrio, cumpre transcrever parte da decisão proferida pelo Tribunal de Justiça do Estado do Rio de Janeiro e publicada na RT 713/121, na qual concluiu-se que "se in casu, o réu não é domiciliado no Brasil, nem se trata de obrigação que aqui se tenha de cumprir, nem a causa versa sobre imóveis situados no Brasil, a Justiça Brasileira não é competente." A ementa do acórdão é a seguir transcrita: "Competência - Internacional - Contrato epistolar - Celebração em Londres com resseguradora - Contratantes domiciliados em países distintos-Competência, para a apreciação da matéria, do lugar em que reside o proponente - Art. $9^{\circ}, \S 2^{\circ}$, da Lei de Introdução ao Código Civil - Incompetência da Justiça Brasileira - Recurso não provido."

${ }^{40}$ In: A lei e o foro de eleição em contratos internacionais. Contratos Internacionais. $2^{\mathrm{a}}$ ed., revista e ampliada, Coordenador João Grandino Rodas, São Paulo: Revista dos Tribunais, 1995, p. 114-115. ${ }^{41}$ Neste sentido, vide decisão do Tribunal de Justiça do Estado do Rio de Janeiro (Agravo de Instrumento $\mathrm{n}^{\circ}$ 1995.002.2155, Quarta Câmara Cível, Rel. Des. Wilson Marques, j. 14.05.1996, unânime), cuja ementa é a seguir transcrita: "Competência. Interna e internacional. Réu domiciliado no Brasil. Competência da autoridade judiciária brasileira. Incompetência da autoridade judiciária estrangeira. Código de Processo Civil. Artigo 88, I. Aplicação. É competente a autoridade judiciária brasileira quando o réu, qualquer que seja sua nacionalidade, estiver domiciliado no Brasil. Não altera essa regra de competência alegação da parte no sentido de que os atos reputados ilícitos foram praticados por empresa com sede no estrangeiro, em face da qual nenhuma ação foi proposta. Decisão interlocutória confirmada. Agravo improvido."
} 
de Bustamante, eis que a nacionalidade foi expressamente consagrada no artigo $318^{42}$ do mesmo.

Verifica-se, também, que independentemente do lugar no qual o contrato foi celebrado e da nacionalidade das partes contratantes, sendo a obrigação cumprida no Brasil, competente é a autoridade judiciária para o julgamento da controvérsia. Da mesma forma, caso aqui tenha ocorrido o fato gerador da obrigação, a justiça brasileira terá competência concorrente para julgamento da lide.

No tocante à hipótese de agência, filial ou sucursal de pessoa jurídica no Brasil, parece-nos mais apropriado que somente as ações relacionadas às operaçóes e negócios efetivamente realizados no Brasil por estas agências, filiais ou sucursais de pessoas jurídicas estrangeiras devem ser decididas pela justiça brasileira.

Neste sentido, é o entendimento de Celso Agrícola Barbi ${ }^{43}$ acerca do tema ao comentar o parágrafo único do artigo 88: 'Naturalmente, dentro dos princípios que levam os países a limitar sua jurisdição, deve-se interpretar esse parágrafo como aplicável às demandas oriundas de negócios dessas agências, filiais ou súcursais, pois só essas causas é que podem interessar à ordem jurídica do País. Do contrário, um canadense residente em seu país natal poderia vir acionar uma empresa norte-americana por questóes surgidas nos Estados Unidos, e sem qualquer ligação com o nosso País, apenas porque a ré tem agência em nosso País."

Percebe-se, portanto, que os elementos de conveniência que permitem a eleição da justiça brasileira para o julgamento do feito consistem daquelas hipóteses de competência relativa ou concorrente previstas no artigo 88 do Código de Processo Civil Brasileiro. Neste particular, reportamo-nos, ainda, aos comentários relativos ao princípio da efetividade constantes no item 3.4. do presente estudo.

Contudo, é de suma importância mencionar que, tratando-se de hipótese de competência concorrente da justiça brasileira e eventualmente eleito o foro de um país estrangeiro pelas partes contratantes, isto não obsta que a controvérsia seja julgada pela justiça brasileira, independentemente de estar sendo apreciada por corte do foro alienígena.

O Superior Tribunal de Justiça ${ }^{44}$ já teve a chance de se manifestar sobre a matéria, sustentando expressamente que "a cláusula eletiva de foro, em hipótese de competência internacional concorrente, não pode ter o condão de afastar a jurisdição brasileira por violar princípio constitucional", reportando-se à decisão do Tribunal de Justiça de São Paulo, segundo a qual "válida a eleição de um foro estrangeiro, permanece a concorrência, istoé, a

${ }_{42}$ Segundo o artigo 318 do Código de Bustamante, "o juiz competente, em primeira instância, para conhecer dos pleitos a que dê origem o exercício das açōes cíveis e mercantis de qualquer espécie será aquele a quem os litigantes se submetam expressa ou tacitamente, sempre que um deles, pelo menos, seja nacional do Estado contratante a que o juiz pertença ou tenha nele o seu domicílio e salvo o direito local, em contrário. A submissão não será possivel para as ações reais ou mistas sobre bens imóveis, se a proibir a lei da sua situação."

${ }^{43}$ In: Comentários ao Código de Processo Civil, vol. I, 10 edição, Rio de Janeiro: Forense, 1998, p. 296.

${ }^{44}$ REsp n²51438/RJ, Quarta Turma, Rel. Min. Barros Monteiro, j. 08.08.2000, DJ 02.10.2000, p. 173, unânime. 
autoridade brasileira não estará impedida de apreciar a matéria; terá competência (ou melhor jurisdição)." Inúmeras são as decisões dos tribunais pátrios ${ }^{45}$, nas quais é consagrado o entendimento de que a cláusula de eleição de foro não afasta a atuação do juiz nacional, quando se tratar de hipótese de competência concorrente da justiça brasileira.

Com efeito, caso a justiça brasileira seja internacionalmente competente para julgar a controvérsia, verifica-se que a jurisprudência pátria tem sustentado que a cláusula contratual de eleição de foro alienígena e o julgamento da controvérsia perante foro estrangeiro não afastam a possibilidade da lide ser julgada pela autoridade judiciária brasileira desde que a decisão estrangeira ainda não tenha sido homologada pelo Supremo Tribunal Federal, a partir do que produzirá efeitos de coisa julgada no território nacional.

${ }^{45} \mathrm{Em}$ relação à competência concorrente da Justiça brasileira, cumpre transcrever as seguintes ementas acerca do tema, demonstrando que, mesmo eleito pelas partes foro alienígena, isto não obsta o julgamento da causa pelo juiz nacional, por tratar-se de hipótese de competência concorrente: "Tratando-se de ação versando sobre contrato que, a teor do art. 1.087 do CC, se presume celebrado no Brasil, em tema de competência internacional se está diante da jurisdição concorrente, que admite a atuação paralela da jurisdição estrangeira sobre a mesma causa sujeita à jurisdição brasileira. Assim, embora válida a eleição de um foro alienigena, é inaceitável que tal cláusula afaste a jurisdição nacional, cuja autoridade não está impedida de apreciar a matéria." (RT 632/82). O Tribunal de Justiça do Estado do Paraná também já decidiu que "tratando-se de causa originária de fato ocorrido no Brasil, a justiça brasileira tem competência concorrente (CPC, art. 88, inciso III), pelo que a cláusula contratual de eleição de foro estrangeiro nāo afasta a jurisdição nacional." (TJPR, Agravo de Instrumento no 76753100, Quinta Câmara, Rel. Des. Cyro Crema, j. 10.08.1999, unânime). Este mesmo Tribunal (TJPR, Al, Primeira Câmara Cível, Rel. Des. Vidal Coelho, 13.11.1995) decidiu, em caso de contrato de compra e venda com assistência técnica celebrado no Brasil, com cláusula de eleição de foro dos tribunais ingleses que "a eleição de foro estrangeiro não afasta a competência da justiça brasileira para conhecer de feito oriundo de contrato celebrado no Brasil e que aqui deve ser cumprido." O Tribunal de Justiça de São Paulo entendeu que "se a obrigação é de ser cumprida no Brasil, a competência da justiça brasileira é inafastável", ainda que a controvérsia relativa ao acordo de acionistas elaborado no exterior entre duas empresas estrangeiras, objetivando disciplinar a distribuição de dividendos de empresa brasileira, já estivesse sendo objeto de ação em trâmite perante os Estados Unidos da América, tendo lá a corte local decidido ser competente para julgar a demanda (TJSP, Câmara Especial, Al 3.124-0, Rel. Des. Andrade Junqueira, unânime, j. 17.11.1983). Da mesma forma, a Oitava Câmara do Tribunal de Alçada Civil do Estado de São Paulo (Agravo de Instrumento $n^{\circ}$ 610.580-8, Rel. Juiz Manoel Mattos, j. 06.02.1995, v.u., in JTACSP, volume 152, p. 14) entendeu que "pouco importa que as partes tenham eleito foro estrangeiro, pois ai estaremos diante de jurisdição concorrente, que não obsta a atuação da justiça brasileira", conforme ementa a seguir transcrita: "Competência internacional. Eleição de foro estrangeiro. Responsabilidade civil. Transporte marítimo. Indenização de seguradora sub-rogada nos direitos do segurado. Contrato celebrado no Brasil. Artigo 88, inciso III, do Código de Processo Civil. Jurisdição concorrente não obsta a ação da justiça brasileira. Competência da justiça brasileira. Preliminar de incompetência rejeitada." O Tribunal de Justiça do Estado do Rio de Janeiro (Agravo de Instrumento no 3415/97, Terceira Câmara Cível, Rel. Des. Antonio Eduardo F. Duarte, j. 10.03.1998), por sua vez, decidiu que "consoante o art. 88 e incisos do CPC, é competente a autoridade judiciária brasileira quando o réu, qualquer que seja a nacionalidade, estiver domiciliado no Brasil, ou mesmo se a ação se originar de fato ocorrido ou de ato praticado no território nacional. Também é certo que, se a obrigação deve ser cumprida neste País, afastada não pode ser tal competência, ainda que admitido o compromisso arbitral, posto ser concorrente e tratar-se, nesse caso, de norma de direito público, já contida no art. 12 da Lei de Introdução ao Código Civil, não podendo ser abolida por vontade das partes, ou seja, a convenção não tem força de obstar o acesso aos Tribunais do País por qualquer interessado." 
Neste diapasão, é também importante mencionar o disposto no artigo 90 do Código de Processo Civil, segundo o qual "a ação intentada perante tribunal estrangeiro não induz litispendência, nem obsta a que a autoridade judiciária brasileira conheça da mesma causa e das que lhe são conexas."

Desta forma, o fato de uma ação já estar em curso perante a justiça de outro país não obsta que a causa seja também aqui ajuizada e julgada, desde que a justiça brasileira também seja internacionalmente competente para o julgamento do feito.

Em relação à litispendência, Arruda Alvim ${ }^{46}$ esclarece, no entanto, que "a existência de convençáo internacional, desde que os Estados a ela tenham aderido, derroga a regra geral da irrelevância da lide no estrangeiro, como no caso do Brasil." Assim sendo, eventualmente poderá a existência de processo tramitando no Estrangeiro impedir o ajuizamento da mesma ação no território nacional, como ocorre, por exemplo, no caso de ação em que são partes países signatários do Código de Bustamante ${ }^{47}$, dentre os quais se inclui o Brasil ${ }^{48}$ e também açôes entre nacionais do Brasil e França, por força do disposto no Acordo de Cooperação em Matéria Civil entre o Governo da República Federativa do Brasil e o Governo da República Francesa, celebrado em 28.05.2000, e internalizado em nosso país, através do recente Decreto no 3.598 , de 12.09.200049.

Questão interessante é também abordada por Arruda Alvim ${ }^{50}$, no que tange à existência de duas decisões judiciais proferidas em diferentes países e com diferentes resultados. Neste caso, ressalta, apesar de admitir hipóteses nas quais a coisa julgada no estrangeiro prevaleça sobre a decisão nacional, que a preferência será pela primeira decisão proferida (com força de coisa julgada) e no caso de dúvida, deve-se pender pela jurisdição nacional. Celso Agrícola $\mathrm{Barbi}^{51}$, por sua vez, sustenta que, nestas hipóteses, o legislador pátrio consagrou a preferência pela sentença brasileira, quando houver ação idêntica no Brasil, antes de passar em julgado a sentença estrangeira.

De qualquer forma, é recomendável, portanto, que caso uma das partes contratantes seja brasileira, verificar as disposiçōes contidas no ordenamento jurídico

\footnotetext{
${ }^{46}$ In: Competência Internacional. Revista de Processo n 7-8, Ano II, Julho-Dezembro de 1977, p. 37.

${ }^{47}$ Dispõe o artigo 314, do Código de Bustamante que "a litispendência, por motivo de pleito em outro Estado contratante, poderá ser alegada em matéria cível, quando a sentença proferida em um deles, deva produzir, no outro, os efeitos de coisa julgada."

${ }^{48}$ Note-se que somente quinze países americanos aderiram e ratificaram o Código de Bustamante, dentre os quais não estão incluidos a Argentina, Uruguai e Paraguai. No Brasil o Código foi ratificado e internado no nosso ordenamento jurídico através do Decreto n 18.871, de 13.08.1929.

${ }^{49}$ Dispōe o artigo 18 do referido Acordo de Cooperação em Matéria Civil, no seu item "1", letra "f", que "as decisōes proferidas pelos tribunais de um dos dois Estados serão reconhecidas e poderão ser declaradas executórias no território de outro Estado, se reunirem as seguintes condições: (...) f) que um litígio entre as mesmas partes, fundado sobre os mesmos fatos e tendo o mesmo objeto que aquele no território onde a decisão foi proferida: (i) não esteja pendente perante um tribunal do Estado requerido, ao qual se tenha recorrido em primeiro lugar; ou (ii) não tenha dado origem a uma decisão proferido no território do Estado requerido em data anterior àquele da decisão apresentada para exequatur; ou (iii) não tenha dado origem a uma decisão proferida no território de um terceiro Estado em data anterior àquela da decisão apresentada para exequatur, e que reúna as condições necessária spara seu reconhecimento no território do Estado requerido."

50 In: Revista de Processo no 7-8, Ano II, Julho-Dezembro de 1977, p. 45.

51 In: Comentários ao Código de Processo Civil, $10^{\mathrm{a}}$ ed., Rio de Janeiro: Forense, 1998, p. 300.
} 
pátrio, em especial no que tange às regras de competência internacional, tendo em vista a possibilidade de eventual foro estrangeiro eleito ser desconsiderado e a controvérsia ser julgada também pela autoridade judiciária brasileira.

Outra questão diretamente relacionada com a necessidade de existência de um dos elementos de conveniência previstos na legislação pátria é a que se refere à possibilidade das partes estipularem um foro neutro para julgamento das controvérsias.

Neste particular, novamente valemo-nos dos ensinamentos de José Inácio Gonzaga Franceschini ${ }^{52}$, segundo o qual não poderá ser eleito foro neutro pelas partes, quando inexista algum elemento de conexão admitido pelo Direito Processual Internacional Brasileiro. Apesar da matéria não ter sido ainda objeto de ampla análise e discussão pela doutrina nacional, verifica-se que o então Tribunal de Alçada do Estado do Rio Grande do Sul sustentou a incompetência do foro de Porto Alegre sob o argumento de que seria neutro para as partes ${ }^{53}$.

De tudo o que foi exposto até o presente momento, constata-se que as normas referentes à competência internacional brasileira são de suma importância não somente para fixar o campo de liberdade das partes para estabelecerem cláusulas eletivas de foro, mas também para verificar em quais hipóteses o juiz nacional, internacionalmente competente de acordo com as regras processuais do ordenamento jurídico brasileiro, também poderá julgar o feito, independentemente do previamente disposto pelas partes acerca da matéria.

\subsubsection{COMPETENNCIA ABSOLUTA}

Dispõe o artigo 89, inciso I, do Código de Processo Civil Brasileiro que compete à autoridade judiciária brasileira, com exclusão de qualquer outra, conhecer de açóes relativas a imóveis situados no Brasil. Neste mesmo sentido é também o contido no artigo 12, § 1ำ da Lei de Introdução ao Código Civil Brasileiro, segundo o qual "só a autoridade judiciária brasileira compete conhecer das ações relativas a imóveis situados no Brasil.”

Trata-se de hipótese de competência absoluta da justiça brasileira e, portanto, caso o contrato a ser celebrado tenha por objeto bem imóvel localizado no Brasil e eventual discussão judicial venha a versar sobre direitos relativos ao mesmo, não poderão as partes, por via de conseqüência, pactuarem cláusula elegendo como competente foro diverso do brasileiro, eis que afastada qualquer liberdade das partes neste particular.

\footnotetext{
${ }^{52}$ In: A lei e o foro de eleição em contratos internacionais. Contratos internacionais. $2^{\mathrm{a}}$ ed. Revista e ampliada, Coordenador João Grandino Rodas, São Paulo: Revista dos Tribunais, 1995, p. 91-145. ${ }^{53}$ Cumpre transcrever a ementa do referido acórdão proferido no Agravo de Instrumento no 184024701 da $4^{\text {a }}$ Câmara Cível do Tribunal de Alçada do Rio Grande do Sul, Rel. Des. Décio Antônio Erpen, julgamento em 28.06.1984: "Transporte marítimo internacional. Foro de eleição. Validade da avença. Mesmo que não houvesse tal cláusula, ainda assim o foro de Porto Alegre seria incompetente porque neutro para as partes. Outros preceitos incidiriam para se precisar o foro. Mas, o que de Porto Alegre, à evidência que não é o competente. Agravo desprovido. Despacho mantido."
} 
Cumpre por oportuno frisar que o artigo 89, inciso I, do Código de Processo Civil Brasileiro refere-se a toda e qualquer ação relativa a bem imóvel localizado no território brasileiro ${ }^{54}$, abrangendo, assim, não somente as ações reais, mas também as pessoais e inclusive às relativas à falência ${ }^{55}$.

Celso Agrícola Barbi ${ }^{56}$, ao comentar o inciso I do referido artigo 89, do Código de Processo Civil Brasileiro, ressalta que "o texto é amplo, não se restringindo a açōes reais, isto é, fundadas em direito real; a lei abrange qualquer ação relativa a bem imóvel, vale dizer, também as fundadas em direito obrigacional, como, v.g., a locação, a promessa de compra e venda e casos semelhantes. Não importa o tipo de ação, istoé, o ser ela condenatória, declaratória ou constitutiva; o que prevalece é a relação entre o direito alegado e um imóvel. Existindo esta vinculação, a competência da Justiça brasileira afasta qualquer outra."

Ainda que as partes tenham livremente pactuado a eleição do foro do país estrangeiro e o juiz de outro país se considere competente para julgar a controvérsia, referida sentença não será homologada pelo Supremo Tribunal Federal, o qual exige, dentre outros requisitos que a decisão tenha sido proferida por juiz competente ${ }^{57}$.

Conclui-se, portanto, que tratando-se de hipótese de competência exclusiva da justiça brasileira, mesmo que ambas as partes sejam estrangeiras, eventual sentença estrangeira não será homologada e, portanto, não surtirá seus efeitos nem poderá ser executada no território brasileiro.

Da mesma forma, compete exclusivamente à autoridade judiciária brasileira, por força do disposto no artigo 89, inciso II, do Código de Processo Civil Brasileiro, proceder a inventário e partilha de bens, situados no Brasil, ainda que o autor da

\footnotetext{
${ }^{54}$ Conforme sustenta DINIZ, Maria Helena. In: Lei de Introdução ao Código Civil Interpretada. $5^{\text {a }}$ ed. Atualizada, São Paulo: Ed. Saraiva, p. 314, o artigo 12, § 10, da LICC e o artigo 89, I, do Código de Processo Civil não abrangem apenas às ações reais imobiliárias, mas todas as ações concernentes à imóveis situados no Brasil. Neste sentido, é também o posicionamento de MOREIRA, José Carlos Barbosa. In: Problemas Relativos à Litígios Internacionais, Revista de Processo n 65, Janeiro-Março de 1992, p. 147, sustentando que o artigo 89, I, do Código de Processo Civil abrange quaisquer ações. ${ }^{55} \mathrm{O}$ Supremo Tribunal Federal (AgRg SE n².492, 03.03.1982, in RTJ 101/69) já decidiu que "toda $e$ qualquer ação, inclusive de falência, relativa a imóvel situado no Brasil é de competência exclusiva da autoridade brasileira, com exclusão de qualquer outra." Este também foi o posicionamento adotado, quando do Pedido de Homologação de Sentença Estrangeira ํo 3.989, no qual sustentou-se que "o dispositivo do $C P C$, acima referido, réplica do art. 12, $\S 1,0$, da $L I C C$, há de ser entendido de modo amplo e compreensivo, não se restringindo à consideração das tipicamente reais, como bem demonstrado pelo ilustre processualista Arruda Alvim (Competência Internacional, in RP 7-8/32), mas às que sejam a eles concernentes ou pertinentes, como é a que se propôs em Portugal, tendo como objeto os referidos imóveis." (Rel. Min. Rafael Mayer, j. 01.12.1987, DJ 14.12.1987, RTJ 123, p. 893), ${ }^{56}$ In: Comentários ao Código de Processo Civil. Volume I, $10^{\mathrm{a}}$ ed., Rio de Janeiro: Forense. 1998, p. 298.

${ }^{57}$ Segundo o artigo 217, do Regimento Interno do Supremo Tribunal Federal, "constituem requisitos indispensáveis à homologação da sentença estrangeira: I - haver sido proferida por juiz competente; II - terem sido as partes citadas ou haver-se legalmente verificado a revelia; III - ter passado em julgado e estar revestida das formalidades necessárias à execução no lugar em que foi proferida; IVestar autenticada pelo cônsul brasileiro e acompanhada de tradução oficial."
} 
herança seja estrangeiro e tenha residido fora do território nacional ${ }^{58}$. Neste particular, sustenta-se que este dispositivo legal abrange não somente os bens imóveis, mas também os móveis ${ }^{59}$ situados no Brasil. Celso Agrícola Barbi ${ }^{60}$ esclarece que "o conceito de bens no artigo é amplo, abrangendo imóveis, semoventes e móveis. Assim, inclui qualquer espécie dessa última classe, como títulos cambiais, depósitos bancários, dinheiro em moeda, açôes, direitos de crédito em geral, etc."

Constata-se que em ambas as hipóteses mencionadas no artigo 89, do Código de Processo Civil Brasileiro, a competência jurisdicional será sempre da autoridade judiciária brasileira, não podendo a competência ser alterada, eis que indisponível. Como visto, eventual pedido de homologação de sentença estrangeira que abranja qualquer uma das referidas situações acima analisadas, não será homologada pelo Supremo Tribunal Federal e, portanto, não surtirá efeitos no território nacional.

\subsection{TIPOS CONTRATUAIS E LEGISLAÇÃO ESPECÍFICA}

Além das normas contidas no Código de Processo Civil e na Lei de Introdução do Código Civil, há inúmeros dispositivos legais relativos a tipos contratuais específicos que versam sobre a competência e devem ser considerados quando da delimitação da cláusula de eleição de foro, obsèrvadas as circunstâncias presentes no caso concreto.

Note-se que, em relação aos contratos a seguir abordados, a pactuação de cláusula de eleição de foro é normalmente vedada por entender que se tratam de hipóteses de competência absoluta, sem que as partes possam livremente dispor de forma diversa daquela prevista na legislação relativa ao tema.

A abordagem de alguns tipos contratuais, nos quais se sustenta a competência absoluta da justiça brasileira para julgamento do feito, não é exaustiva e objetiva demonstrar que a negociação de qualquer contrato, além dos abaixo indicados, deve

${ }^{58}$ Note-se que, conforme esclarece CARNEIRO, Athos Gusmão. In: Jurisdição e Competência. 9ª ed., São Paulo: Ed. Saraiva, 1999, p. 55, o artigo 89, inciso II, do Código de Processo Civil Brasileiro não somente é aplicável ao inventário e partilha causa mortis, como também ao inventário e partilha conseqüentes à separação judicial e ao divórcio. Neste sentido, o referido Autor menciona decisão do Supremo Tribunal Federal (Presidência, 27.06.1980, RTJ 96/569), segundo a qual não pode ser homologada no Brasil sentença estrangeira que, em ação de divórcio julgada em Portugal, haja procedido a partilha envolvendo bens móveis e imóveis situados no Brasil.

59 Pontes de Miranda, In: Comentários ao Código de Processo Civil, Tomo II, Rio de Janeiro: Ed. Forense, 1973, p. 195-196, ao analisar o artigo 89, inciso II, do Código de Processo Civil, defende que sāo considerados bens situados no Brasil as coisas móveis que no Brasil se achem (e.g. mobiliário, carros, barcos, cofres, jóias, dinheiro). Considera, também, bem móvel situado no Brasil (i) as açōes de empresas brasileiras e as estrangeiras com filial ou agência no Brasil, eis que a "ação é título eo bem, que ela exibe, está no ato constitutivo da empresa situada no Brasil"; (ii) os títulos cambiários ou cambiariformes, desde que não sejam "títulos subscritos e emitidos no exterior por filial ou agência de entidade, estatal, paraestatal ou particular que tenha poder para fazê-lo em nome próprio" e o (iii) dinheiro depositado no Brasil em estabelecimento bancário, desde que inexista "ressalva de ser retirado pela pessoa que o depositou em filial ou agência sediada no estrangeiro, ou com destino a ser remetido em determinada data para o estrangeiro."

60 In: Comentários ao Código de Processo Civil, volume I, 10 edição, Rio de Janeiro: Forense, p. 298. 
ser precedida da análise das normas contidas nos ordenamentos jurídicos das partes envolvidas $^{61}$, a fim de verificar eventuais limitações e restriçóes ao conteúdo das cláusulas contratuais de eleição de foro e, consequentemente, das relativas à lei aplicável ao contrato.

\subsubsection{CONTRATOS DE ADESÃO}

Apesar de não constituir um tipo contratual específico, cumpre, em face da importância do tema, abordar, preliminarmente, a problemática relativa à validade das cláusulas de eleição de foro inseridas em contratos de adesão, pois é mister verificar se as partes livremente estipularam a eleição do foro, sem que houvesse abuso de uma das partes em face de sua posição dominante, dificultando o acesso ao Poder Judiciário para eventual solução de uma controvérsia.

Constata-se que, via de regra, excluem-se os efeitos da cláusula de eleição nos contratos de adesão, ou seja, naqueles contratos celebrados por adesáo de uma das partes contratantes, sem que pudesse discutir acerca de eventual foro eleito.

Contudo, é importante frisar que o simples fato de tratar-se de um contrato de adesão não exclui por si só a validade do foro eleito, já tendo o Superior Tribunal de Justiça ${ }^{62}$ decidido que referida cláusula é válida e eficaz, salvo "se, no momento da celebraçáo, a parte aderente não dispunha de intelecção suficiente para compreender o sentido e as conseqüências da estipulação contratual; se da prevalência de tal estipulação resultar inviabilidade ou especial dificuldade de acesso ao Judiciário; se se tratar de contrato de obrigatória adesão, assim entendido o que tenha por objeto produto ou serviço fornecido comexclusividade por determinada empresa."

\footnotetext{
61 Visando demonstrar a necessidade de analisar as legislaçōes existentes nos países das partes contratantes, reportamo-nos aos comentários de FAWCETT, James J., in: Declining Jurisdiction in Private International Law, Oxford: Clarendon Express, 1995, p. 55-56, o qual menciona, a título exemplificativo, que o Ato Marítimo Sueco de 1994 restringe a liberdade das partes, no tocante às cláusulas de eleição de foro relativas a contratos de transporte marítimo de passageiros e mercadorias. Da mesma forma, a legislação grega considera nula as cláusulas de eleição de foro estrangeiro, quando referentes a contratos de trabalho de cidadãos gregos para prestação de serviços na Ásia ou África. Este mesmo autor menciona, ainda, restrições contidas na legislação suiça e canadense (Quebec) relacionadas à cláusula de eleição de foro em contratos do consumidor.

62 In: REsp 149759/SP (1997/0067906-3), Quarta Turma, Rel. Min. Sálvio de Figueiredo Teixeira, j. 29.06.1998, DJ 21.09.1999, p. 0184, unânime.
} 
Assim sendo, necessário será analisar as circunstâncias presentes no caso concreto $^{63}$, pois "não há contrato de adesão quando as partes contratantes, sendo economicamente iguais, livre e conscientemente assinam contrato concordando com a eleiçáo de foro ${ }^{64}$." Neste mesmo sentido, encontramos inúmeras outras decisões ${ }^{65}$ julgando válida a eleição de foro no direito interno, ainda que em casos de contratos de adesão, se afastada qualquer hipossuficiência ou vulnerabilidade das partes contratantes que pudesse acarretar a abusividade da disposição contratual com base no Código de Defesa do Consumidor Brasileiro.

A validade ou não da cláusula de eleição de foro inserida em contrato de adesão dependerá, portanto, das circunstâncias presentes no caso em concreto, podendo ser invalidada pelo juiz nacional.

Feito este comentário geral em relação aos contratos de adesão, cumpre analisar os tipos contratuais cuja legislação aplicável apresenta algum tipo de limitação no que tange à pactuação da cláusula de eleição de foro em relação aos mesmos.

\footnotetext{
${ }^{63}$ Recentemente, o Supremo Tribunal Federal, em caso de Sentença Estrangeira Contestada (Tribunal Pleno, SEC n 5.847-1/Rieino Unido da Grã Bretanha e da Irlanda do Norte, Rel. Min. Maurício Cardoso, j. 01.12.1999, DJ 17.12.1999, Ementário 1976-2) deferiu o pedido de homologação da mesma, analisando, dentre outras questões, a existência de contrato de adesão, tendo em vista que a parte requerida sustentou a nulidade de cláusula arbitral, alegando que o contrato de compra e venda firmado era de adesāo e, portanto, referida cláusula deveria estar escrita em negrito, como determina 0 artigo $4^{\circ}$, $\S 2^{\circ}$, da Lei 9.307/96. Apesar da questão ser ínsita ao mérito, o Ministro Relator Maurício Cardoso manifestou-se e com base na análise do caso concreto, entendeu que "não é contrato de adesão aquele em que as cláusulas são modificáveis por acordo das partes." Segundo o voto do referido Ministro, "ao compulsarse o documento de fls. 221/222, desponta claro que a empresa vendedora foi livremente escolhida pela TEKA, nada obstante a existência de centenas de outros fornecedores de algodão no mercado internacional. É evidente que o contrato de adesão não é caracterizado pelo impresso com espaços em branco, como crê a requerida, mas pelas condições que uma das partes impóe a outra e não sujeitas a discussão. Na hipótese, as cláusulas insertas na avença dizem respeito ao local em que a mercadoria seria entregue, à forma de conferência de peso, à extensão do seguro, ao pagamento do frete $e$, finalmente, às regras da arbitragem, tudo isso sujeito a modificações, segundo entendimentos prévios. Não consta que contrato de tal configuração jurídica seja de adesão ou que algumas de suas cláusulas possam ser consideradas como leoninas, matéria, ademais, como disse, alheias à natureza do procedimento homologatório."

${ }^{64}$ In: Superior Tribunal de Justiça, REsp 161.548, Primeira Turma, Rel. Min. Garcia Vieira, j. 11.05.1998, DJ 10.08.1998, p. 29, unânime.

${ }^{65}$ A Quarta Turma do Superior Tribunal de Justiça já decidiu que "é válida a cláusula de eleição de foro constante de contrato de valor aproximado de $R \$ 1.000 .000,00$, celebrado por empresa de porte, que se presume tenha condições de exercer a defesa no foro escolhido, embora se trate de contrato de adesão." (RESP 304678/SP, Rel. Min. Ruy Rosado de Aguiar, j. 28.08.2001, DJ 19.11.2001, p. 282). Da mesma forma, a Terceira Turma desta Corte entendeu que "nas relações entre empresas de porte, capazes financeiramente, de sustentar uma causa em qualquer foro, prevalece o de eleiçāo." (RESP 279687/RN, Rel. Min. Castro Filho, DJ 05.08.2002, p. 328). Neste mesmo sentido, a $2^{a}$ Seção do STJ entendeu que "na compra e venda de sofisticadíssimo equipamento destinado a realização de exames médicos levada a efeito por pessoa jurídica nacional e pessoa jurídica estrangeira - prevalece o foro de eleição, seja ou não uma relação de consumo." (CC 32270-SP, Rel. Min. Ari Pargendler, DJ 11.03.2002, p. 159)
} 


\subsubsection{CONTRATOS DE TRABALHO}

Em relação aos contratos de trabalho, a Consolidação das Leis do Trabalho restringe a liberdade contratual no que tange à delimitação do foro competente, regulando expressamente a matéria no seu artigo $651^{66}$, a qual se trata de hipótese de competência exclusiva da justiça brasileira ${ }^{67}$.

Por força do disposto no artigo 651 da Consolidação das Leis do Trabalho, a autoridade judiciária brasileira é competente nos casos de prestação de serviços em território nacional, bem como na hipótese do empregado ser brasileiro, ainda que tenha trabalhado em país estrangeiro, e inexista convenção internacional dispondo em contrário.

Délio Maranhão ${ }^{68}$, ao comentar a matéria, conclui que no ordenamento jurídico brasileiro não é admissível o foro de eleição, até mesmo porque os critérios de fixação da competência, no processo do trabalho brasileiro, atendem a interesse de ordem pública (proteção do empregado e irrenunciabilidade dos benefícios assegurados ao mesmo na forma do que determina o artigo $9^{\circ}$ da CLT) ${ }^{69}$.

Francisco Gérson Marques de Lima ${ }^{70}$ ressalta, ainda, que não há consonância entre o disposto na Consolidação das Leis do Trabalho e o artigo 12 da Lei de Introdução ao Código Civil, segundo o qual "é competente a autoridade judiciária brasileira, quando

\footnotetext{
${ }^{66}$ Dispōe o artigo 651, da Consolidação das Leis do Trabalho que: "Art. 651. A competência das Juntas de Conciliação e Julgamento é determinada pela localidade onde o empregado, reclamante ou reclamado, prestar serviços ao empregador ainda que tenha sido contratado noutro local ou no estrangeiro. $\S 1^{\circ}$ - Quando for parte no dissídio agente ou viajante, é competente a Junta da localidade onde o empregador tiver o seu domicílio, salvo se o empregado estiver imediatamente subordinado à agência, ou filial. $\S 2^{o}$ - A competência das Juntas de Conciliação e Julgamento, estabelecida neste artigo, estende-se aos dissidios ocorridos em agência ou filial no estrangeiro, desde que o empregado seja brasileiro e não haja convenção internacional dispondo em contrário. $\S 3^{o}$ - Em se tratando de empregado que promova a realização de atividades fora do lugar do contrato de trabalho, é assegurado ao empregado apresentar reclamação no foro da celebração do contrato ou no da prestação dos respectivos serviços."

${ }^{67}$ Neste sentido, RUSSOMANO, Mozart Victor. In: Comentários à Consolidação das Leis do Trabalho. Volume IV, $7^{\text {a }}$ edição, Rio de Janeiro: Editor José Konfino, 1966, 1149-1150, menciona duas decisões do Tribunal Superior do Trabalho: "Nula é a eleição prévia de foro diverso daqueles determinados pelo artigo 651, da Consolidaçāo, e pelo seu parágrafo $3^{\circ}$. Não é admissível a renúncia do foro legal no ato da contratação." (Ac. Da $3^{\text {a }}$ Turma do TST, 18.09.1958) e "Foro de eleição. Contrato de trabalho, inadmissibilidade. Competência dos tribunais do trabalho. Caráter tutelar da legislação trabalhista. Aplicação do art. 651, da Consolidação. Inadmissível é a estipulação do foro, pelas partes, no contrato de trabalho, considerando-se não escrita a cláusula que importe escolha de foro, com infração dos critérios legais." (Ac. Do TST, in Trabalho e Segurança Social, 1952, julho/agosto, 305).

${ }_{68}^{68}$ MARANHÃO, Délio e outros. Instituições de Direito do Trabalho, 16ª edição, São Paulo: LTr, p. 1266. 69 Neste sentido, o Tribunal Superior do Trabalho já decidiu que é "ilegal e inoperante no processo trabalhista a eleição de foro em detrimento do empregado, eis que imperativas e de ordem pública as normas do artigo 651 da CLT, ditadas no manifesto de propiciar acessibilidade e facilidade na produção da prova ao litigante economicamente hipossuficiente." (CC 320751, Subseção II Especializada em Dissídios Individuais, $2^{\mathrm{a}}$ Turma, DJ 06.03.1998, p. 243)

70 In: Lei de Introdução ao Código Civil e Aplicação do Direito do Trabalho. São Paulo: Ed. Malheiros. 1996, p. 204-206.
} 
for o réu domiciliado no Brasil, ou aqui tiver de ser cumprida a obrigação", devendo prevalecer o disposto na legislação trabalhista por ser norma mais específica.

Assim sendo, eventual cláusula de eleição de foro em contrato de trabalho internacional, dispondo de forma em contrário ao previsto no artigo 651, a princípio, não prevalecerá sobre as normas contidas na Consolidação das Leis do Trabalho ${ }^{71}$, as quais deverão ser observadas.

\subsubsection{CONTRATOS CELEBRADOS POR FALIDOS}

Da mesma forma, em relação aos contratos celebrados por falidos, eventual cláusula de eleição de foro, a princípio, não prevalecerá sobre o disposto nos artigos $7^{\circ}$ e 156 da Lei de Falências ${ }^{72}$, pois competente é o foro do lugar onde o comerciante devedor tem o seu principal estabelecimento ou casa filial de outra situada fora do Brasil.

Note-se que segundo o artigo $7^{\circ}, \S 2$ o' "o juízo da falência é indivisível e competente para todas ações e reclamaçôes sobre bens, interesses ou negócios da massa falida", ainda que eventualmente a regra da universalidade encontre limitaçóes, inclusive no que tange os foros especiais e exceções previstas na própria Lei de Falências ${ }^{73}$. Oscar Tenório ${ }^{74}$, ao comentar a matéria, sustenta que o direito brasileiro conforma-se, via de regra, com a teoria da universalidade, desde que assentada na regra do domicílio, estabelecendo, ainda, a supremacia da justiça brasileira para o decreto e o processo de falência de comerciantes brasileiros domiciliados e estabelecidos em território nacional.

Em face do disposto na Lei de Falências, conclui-se que embora as partes tenham livremente eleito foro no estrangeiro para julgar quaisquer controvérsias originárias do contrato celebrado entre as mesmas, esta disposição poderá ser afastada em face do

\footnotetext{
${ }^{71}$ Note-se que o Tribunal Superior do Trabalho recentemente decidiu que é inoperante no processo trabalhista a eleição de foro diverso do previsto no artigo 651 da Consolidação das Leis do Trabalho, conforme ementa a seguir transcrita: "Justiça do Trabalho. Competência territorial. Foro de Eleição. Dissídio Individual. Artigo seiscentos e cinqüenta e um, parágrafo terceiro, da CLT. 1. llegal e inoperante no processo trabalhista a eleição de foro em detrimento do empregado, eis que imperativas e de ordem pública as normas do artigo seiscentos e cinqüenta e um, da CLT, ditadas no escopo manifesto de propiciar acessibilidade e facilidade na produção da prova ao litigante economicamente hipossuficiente. 2. O empregado demandante pode optar entre o foro da celebração do contrato e o da efetiva prestação do trabalho (artigo seiscentos e cinqüenta e um, parágrafo terceiro, da CLT. 3. Havendo pré-contratação verbal do empregado, em determinada localidade, na qual é recrutado, selecionado, informado através de palestras sobre a remuneração, bem assim onde ocorrera o futuro treinamento, tem-se esta como localidade da celebração do contrato de trabalho, para fixação da competência territorial, ainda que a formalização do contrato dê-se em outro município." (TST, Subseção II Especializada em Dissídios Individuais, CC 320751, Min. Relator João Orestes Dalazen, j. 02.12.1997, DJ 06.03.1998, p. 243).

${ }^{72}$ Decreto-Lei no 7.661, de 21.06.1945.

${ }^{73}$ Vide os comentários de CARNEIRO, Athos Gusmão. In: Jurisdição e Competência. 9a ed. São Paulo: Ed. Saraiva, 1999, p. 105-106.

${ }^{74}$ In: Direito Internacional Privado. Volume II, $11^{\mathfrak{a}}$ edição, revista e atualizada. Rio de Janeiro: Freitas Bastos, 1976, p. 247-262.
} 
que dispõe a legislação brasileira em matéria falimentar ${ }^{75}$, salvo se eventualmente previsto um foro especial ou no caso das exceções expressamente estipuladas na legislação aplicável à matéria.

\subsubsection{CONTRATOS ADMINISTRATIVOS}

José Inácio Gonzaga Franceschini ${ }^{76}$ ressalta a inadmissibilidade das cláusulas de eleição de foro em relação aos contratos administrativos, tendo em vista serem os mesmos regidos por preceitos de Direito Público, os quais vedam foro diverso do que o brasileiro para julgamento de quaisquer controvérsias.

A legislação atual - Lei 8.666/93, com as alterações introduzidas pela Lei 8.883, de 08.06.1994 - que rege os contratos administrativos e licitaçōes no ordenamento jurídico pátrio relacionou, em seu artigo $55^{77}$, treze cláusulas consideradas essenciais em todo contrato administrativo, impondo a obrigatoriedade, nos contratos celebrados pela Administração Pública com pessoas físicas ou jurídicas, inclusive aquelas domiciliadas no estrangeiro, de inserir cláusula que declare competente o foro da sede da Administração para dirimir qualquer questão contratual, salvo o disposto no $§ 6^{\circ}$ do art. 32 desta Lei, o qual abrange as hipóteses de concorrência internacional e contratação, mediante prévia autorização do Chefe do Poder Executivo.

Importante mencionar que a cláusula declarando competente o foro da sede da Administração é essencial ao contrato administrativo, não podendo, portanto, faltar no mesmo, sob pena de nulidade do instrumento.

Não há, portanto, liberdade das partes de convencionarem foro diverso do previsto em lei ou, ainda, omitirem esta disposição do contrato administrativo, sob pena de acarretar a nulidade do mesmo.

\footnotetext{
${ }^{75} \mathrm{Em}$ relação à matéria falimentar em sede de contratos internacionais, menciona-se decisão do Tribunal de Justiça do Rio de Janeiro, na qual é sustentada a impossibilidade de apreciação desta matéria no âmbito do direito internacional privado, conforme ementa a seguir transcrita: "Ação Ordinária de cobrança. Competência firmada da justiça brasileira. Suspensão de pagamento de lei dinamarquesa e concordata brasileira. Credor quirografário. Os atos de comércio tem caráter territorial. Incabivel apreciação de matéria falimentar no âmbito do direito internacional privado." (Quarto Grupo de Câmaras Cíveis, Embargos Infringentes na Apelação Cível no 1987.005.3947, Rel. Des. Fernando Whitaker, j. 15.12.1988, unânime, Ementário 01/98, № 113, 23.03.1989)

${ }^{76} \mathrm{In}$ : A lei e o foro de eleição em contratos internacionais. Contratos Internacionais. $2^{\mathrm{a}}$ ed., revista e ampliada, Coordenador João Grandino Rodas, São Paulo: Revista dos Tribunais, 1995, p. 110.

77 Dispõe o artigo 55, parágrafo $2^{\circ}$, da Lei 8.666/93 que "nos contratos celebrados pela Administração Pública com pessoas físicas ou jurídicas, inclusive aquelas domiciliadas no estrangeiro, deverá constar necessariamente cláusula que declare competente o foro da sede da Administração para dirimir qualquer questão contratual, salvo o disposto no $\S 6^{\circ}$ do art. 32 desta Lei." O referido parágrafo $6^{\circ}$ do artigo 32 estabelece, por sua vez, que "o disposto no $\S 4^{\circ}$ deste artigo, no $\S 1^{\circ}$ do artigo $33 \mathrm{e}$ no $\S 2^{\circ}$ do art. 55 não se aplica às licitaçōes internacionais para a aquisição de bens e serviços cujo pagamento seja feito com o produto de financiamento concedido por organismo financeiro internacional de que o Brasil faça parte, ou por agência estrangeira de cooperação, nem nos casos de contratação com empresa estrangeira, para a compra de equipamentos fabricados e entregues no exterior, desde que para este caso tenha havido prévia autorização do Chefe do Poder Executivo, nem nos casos de aquisiçāo de bens e serviços realizada por unidades administrativas com sede no exterior."
} 


\subsubsection{CONTRATOS DE REPRESENTAÇÃO COMERCIAL}

No caso de contratos de representação comercial, a legislação pátria que rege os mesmos prevê, expressamente, que é competente o foro do domicílio do representante comercial. A doutrina e a jurisprudência nacionais, contudo, não são unânimes, ora entendendo que o disposto no referido artigo 39, da Lei 4.886/65, deve ser considerado como regra de competência absoluta, ora como de competência relativa e, portanto, suscetível de ser modificado e convencionado de forma diversa pelas partes ${ }^{78}$.

Em oposição à eleição de foro nos contratos de representação comercial firmados com representantes comerciais brasileiros, impondo a observância da regra de competência contida no artigo 39 da Lei 4.886/65, com a redação dada pela Lei 8.420/92, destaca-se o posicionamento de renomados doutrinadores e até mesmo do próprio Superior Tribunal de Justiça ${ }^{79}$.

Neste particular, Beat Walter Rechsteneiner ${ }^{80}$ sustenta que a competência é absoluta da justiça brasileira no caso de representação comercial, defendendo que "por motivo de ordem pública, a justiça brasileira é competente, internacionalmente, com exclusão de qualquer outra estrangeira, quando a questão versada incidir sobre determinadas situaçóes,

\footnotetext{
${ }^{78}$ Neste sentido, menciona-se decisāo do Supremo Tribunal de Justiça STJ, REsp 110104/SP, Terceira Turma, Min. Rel. Waldemar Zveiter, maioria, j. 24.11.1998, DJ 26.04.1999, p. 89), a seguir transcrita: "Ação de cobrança. Contrato de Representação Comercial. Competência. Na forma de precedente da $2^{a}$ Seção, a 'competência estabelecida pelo artigo 39 da Lei 4.886/65, com a redação dada pela Lei 8.420/92, é de natureza relativa, podendo, pois, ser modificada pela vontade das partes, na forma da parte final do artigo 111 do CPC. Conflito conhecido, declarando-se a competência do MM. Juizo suscitante.,' Recurso Especial não conhecido."

${ }^{79} \mathrm{O}$ posicionamento do Superior Tribunal de Justiça não é uniforme no que tange à cláusula de eleição de foro em contratos de representação comercial. Transcrevem-se duas decisões, sustentando a competência absoluta do foro do domicilio do representante comercial: "Foro de eleição. Representação Comercial. Contrato de Adesão. O foro de eleição previsto no contrato de adesão, porque significa dificuldade de acesso à Justiça, nāo tem validade. Tratando-se de contrato de representação comercial, a Lei. 4.886/65, com a redação da Lei 8.420/92, fixa a competência do foro do domicílio do representante. Recurso não conhecido." (STJ, 4⿳亠口冋 Turma, REsp 47074/MG, Rel. Min. Ruy Rosado de Aguiar, unânime, j. 29.11.1994, DJ 06.02.1995, p. 01358) e "Recurso Especial. Contrato de Representação Comercial. Foro de Eleição. Desconsideração. Foro de Domicílio do Representante. Lei 4.886/65, Art. 39, Precedentes. Recurso Acolhido. 1 - A cláusula de eleição de foro inserida em contrato de adesão é, em princípio válida e eficaz, salvo: a) se, no momento da celebração, a parte aderente não dispunha de intelecção suficiente para compreender o sentido e as consequências da estipulação contratual; $b$ ) se da prevalência de tal estipulaçāo resultar inviabilidade ou especial dificuldade de acesso ao Judiciário; c) se se tratar de contrato de obrigatória adesão, assim entendido o que tenha por objeto produto ou serviço fornecido com exclusividade por determinada empresa. II - Não reconhecida qualquer dessas circunstâncias, é de prevalecer o foro eleito. III - Em se tratando, todavia, de contrato de representação comercial, a cujo respeito há disposição expressa de lei a determinar o foro do domicílio do representante como sendo o lugar apropriado para a solução do litígio estabelecido entre as partes contratantes (art. 39 da Lei 4.886/65, modificado pela Lei 8.420/92), entende a Turma que não há de prevalecer o foro eleito por adesão." (STJ, $4^{a}$ Turma, REsp 149758/SP, Rel. Min. Sálvio de Figueiredo Teixeira, unânime, j. 24.06.1998, DJ 21.09.1998, p. 184) O Tribunal de Justiça do Estado do Rio Grande do Sul já firmou posicionamento semelhante ao decidir, em relação a um contrato de representação comercial, que "havendo disposição expressa da lei própria no tocante ao foro competente para julgamento das controvérsias do contrato, prevalece o disciplinamento legal sobre o foro de eleição." (TJRS, 16ª Câmara Civel, Al no 70000303495, Rel. Des. Helena Cunha Vieira, Porto Alegre, j. 17.11.1999)

${ }^{80}$ In: Direito Internacional Privado. Teoria e Prática, São Paulo: Ed. Saraiva, 1998, p. 201.
} 
tais sejam aquelas decorrentes de um contrato de representação comercial ou que envolvam a tutela do consumidor."

O Tribunal de Justiça do Estado do Rio de Janeiro recentemente decidiu, em caso relativo à contrato internacional de representação comercial, que a justiça brasileira era competente para julgar a matéria, não sendo aplicável a cláusula de eleição de tribunal localizado na França, onde a empresa representada era sediada ${ }^{81}$. Consta no corpo do referido acórdão que "não se pode considerar, como livremente convencionada, cláusula de contrato de representação comercial, em que se adotou foro de eleição, sediado em país estrangeiro, o qual só atende às conveniências e interesses da representada. Isso eqüivale a privar, virtualmente, o representante, parte economicamente mais fraca, de postular a tutela jurisdicional, com reais prejuízos a seus direitos, o que é razão suficiente para se afastar o foro de eleição. Nessa situação, segue-se a disciplina jurídica brasileira, que estabelece, na lei de regência, que o foro competente é o do domicilio do representante, nas demandas daí originárias."

Importante ressaltar, em relação ao caso acima mencionado, que o contrato de representação comercial foi firmado no Brasil e, por via de conseqüência, seria aplicável ao mesmo a legislação brasileira relativa ao tema, a qual determina, expressamente, como competente o foro de domicílio do representante comercial. Entretanto, conclusão contrária poderia ser encontrada, caso o contrato tivesse sido celebrado no exterior, sem nenhuma vinculação com o território nacional, hipótese na qual a justiça brasileira poderia, possivelmente, sustentar sua incompetência para o julgamento do feito $^{82}$.

Percebe-se, portanto, que na eventualidade da controvérsia entre representante comercial brasileiro e empresa representada estrangeira vir a ser julgada no Brasil, há a possibilidade do foro estrangeiro eleito ser desconsiderado pela justiça brasileira, sustentando tratar-se de hipótese de competência exclusiva brasileira, ou ainda, contrato firmado por adesão do representante comercial, com imposição, sem negociação prévia, desta cláusula. Por outro lado, mesmo que não se sustente tratar-se de hipótese de competência absoluta da justiça brasileira, quando aqui domiciliado o representante comercial, é também provável que eventual cláusula eletiva de foro estrangeiro seja

\footnotetext{
${ }^{81}$ Note-se que o caso em tela demonstra que a questão da cláusula de eleição de foro em contratos de representação comercial não é pacífica, tendo em vista que a decisão do Tribunal de Justiça do Estado do Rio de Janeiro não foi unânime, tendo-se sustentado, no voto vencido, a validade da eleição do foro pactuado pelas partes contratantes, o que retiraria da justiça brasileira o conhecimento da situação conflituosa, em face da argüição de exceção de incompetência levantada pela empresa representada (TJRJ, Agravo de Instrumento $n^{\circ} 1.190 / 98$, Oitava Câmara Cível, Agravante: Karl Heinz Angermann; Agravada: Verrerie Cristallerie D'Arques, J.G. Furand \& Cie.; Rel. Des. Luiz Odilon Gomes Bandeira, vencido, j. 19.05.1998, DOERJ 15.10.1998, in Revista Jurídica ํㅡ 259, Maio de 1999, p. 67-70).

${ }^{82}$ Neste sentido já entendeu o Tribunal de Alçada do Estado de São Paulo (TAC, Agravo de Instrumento nº 0710629-2, Sexta Câmara Cível, Rel. Juiz Evaldo Veríssimo, unânime, j. 19.11.1996, in JTALEX 164/43), conforme ementa a seguir transcrita: "Competência recursal - Foro de eleição - Contrato de representação comercial firmado no exterior, segundo a legislação do país da empresa estrangeira contratante - Inexistência de afronta à jurisdição brasileira - Competência concorrente da justiça brasileira admitida na hipótese de existência das situações definidas nos incisos do artigo 88 do Código de Processo Civil, o que inocorre no caso - Exceção de incompetência acolhida - Recurso improvido."
} 
desconsiderada, sob o argumento de que tendo a justiça brasileira competência concorrente para o julgamento do feito, não poderia a cláusula, por via de conseqüência, afastar a atuação do juiz estatal nacional.

Assim sendo, no caso de celebração de contrato desta natureza com representante comercial brasileiro, deverá ser considerado o disposto no artigo 39, da Lei 4.886/65, com a redação da Lei 8.420/92, além dos posicionamentos passíveis de serem adotados e, em especial, quando haja violação à ordem pública ou contratação por adesāo do representante, sem possibilidade de negociação prévia do conteúdo das disposições contratuais.

\subsection{PRINCÍPIODA EFETIVIDADE}

Ainda que inexista qualquer óbice - violação à ordem pública ou eventual limitação legal como, por exemplo, aquela prevista no artigo 89 do Código de Processo Civil Brasileiro - à validade da cláusula de eleição de foro, é importante mencionar que há hipóteses nas quais a cláusula é afastada por decisão judicial em que o Poder Judiciário Brasileiro dá-se por incompetente, alegando a ausência de interesse no julgamento do feito perante o ordenamento jurídico nacional.

Desta forma, após a análise das diversas limitações existentes no ordenamento jurídico pátrio no que tange à cláusula de eleição de foro, cumpre também mencionar que esta não subsiste em face do princípio da efetividade.

Ressalte-se que, inobstante fossem admitidas outras hipóteses da competência brasileira que não aquelas expressamente mencionadas nos artigos 88 e 89 Código de Processo Civil, exige-se que haja alguma vinculação com o território nacional para que seja incidente a competência internacional da justiça brasileira.

Dentro desta ótica, discute-se se eventualmente eleito o foro de uma cidade no território brasileiro para o julgamento de controvérsia originária de um contrato internacional sem qualquer vinculação com o Brasil, poderia o juiz nacional recusar-se em julgar a ação, sob o fundamento de inexistência de qualquer relação desta com o território brasileiro e impossibilidade de execução da sentença pela justiça local.

Sustenta-se, nestes casos, que por força do princípio da efetividade, "em relação às causas não incluídas nos artigos 88 e 89 do Código de Processo Civil Brasileiro, deve declarar-se internacionalmente incompetente o juiz brasileiro exclusivamente competentes as autoridades judiciárias estrangeiras." 83

É preciso, portanto, para a clara compreensão do tema, verificar o que consiste o princípio da efetividade, o qual é definido por Amilcar de Castro ${ }^{84}$, conforme passagem a seguir transcrita: "O princípio da efetividade significa que o juiz é incompetente para proferir sentença que não tenha possibilidade de executar. É intuitivo que o exercício da

\footnotetext{
${ }^{83}$ MESQUITA, José Ignácio Botelho de. In: Da Competência Internacional e dos princípios que a informam. Revista de Processo no 50, Ano XIII, Abril-Junho de 1988, p. 54.

${ }^{84}$ In: Direito Internacional Privado. $5^{\text {a }}$ edição aumentada e atualizada, Rio de Janeiro: Forense, 1995, p. 537.
} 
jurisdição depende da efetivação do julgado, o que não exclui a possibilidade de ser exercida a respeito de pessoas que estejam no estrangeiro, eportanto fora do poder do tribunal. Oque se afirma é que, sem texto de lei, em regra, o tribunal deve-se julgar incompetente quando as coisas, ou o sujeito passivo, estejam fora de seu alcance, isto é, do alcance da força de que dispóe."

José Ignácio Botelho de Mesquita ${ }^{85}$ também aborda o tema, adotando, no entanto, posicionamento mais flexível do que o de Amilcar de Castro. Segundo este autor, há causas em relação às quais o Estado é juridicamente indiferente, devendo, portanto, serem excluídas das hipóteses de competência internacional do Estado, por faltar efetividade ao exercício da jurisdição nacional.

São três espécies de causas, em relação às quais Botelho de Mesquita ${ }^{86}$ sustenta ser aplicável o princípio da efetividade, excluindo-as das hipóteses de competência internacional: "a) as que demandem aplicação de direito estrangeiro e não sejam suscetíveis de execução no território nacional; $b$ ) as que demandem aplicação do Direito nacional mas a sentença dada não seja suscetível de homologaçằo no país onde deva ser executada; ec) as execuções sobre bens situados fora do território nacional ou referentes a obrigações de cujo título náo conste o Brasil como lugar do cumprimento da obrigação."

Frise-se, no entanto, que o princípio da efetividade não é de todo aceito para o fim de excluir a jurisdição nacional, existindo doutrinadores como José Inácio Gonzaga Franceschini ${ }^{87}$, os quais sustentam que "o princípio da efetividade, segundo oqual o tribunal deve declarar-se incompetente quando não tenha razoável certeza de que poderá executaro julgado não parece, data venia, aceitável, tendo em vista que o Estado não é detentor de um poder de julgar, mas antes de um poder-dever de fazê-lo."

José Inácio Gonzaga Franceschini reporta-se, ainda, aos ensinamentos de Agustinho Fernandes Dias da Silva ${ }^{88}$, segundo o qual "o princípio da efetividade deve ser usado mais para justificar do que para excluir a competência", pois "quando não tenha o juiz nenhuma outra razão para julgar a causa, deverá considerar que, se não o fizer, talvez ninguém mais o poderá fazer com efetividade, e por isso, então julgar."

O próprio José Ignácio Botelho de Mesquita ${ }^{89}$ admite que o princípio da efetividade comporta exceçôes, pois podem existir casos nos quais, apesar da ausência de qualquer relação com os artigos 88 e 89 do Código de Processo Civil Brasileiro, haja

\footnotetext{
85 In: Da Competência Internacional e dos princípios que a informam. Revista de Processo n 50 , Ano XIII, Abril-Junho de 1988, p. 59-60.

${ }^{86}$ In: Direito Internacional Privado. $5^{\text {a }}$ ediçāo aumentada e atualizada, Rio de Janeiro: Forense, 1995, p. 537.

${ }^{87}$ In: A lei e o foro de eleição em contratos internacionais. Contratos Internacionais. $2^{2}$ ed., revista e ampliada, Coordenador João Grandino Rodas, São Paulo: Revista dos Tribunais, 1995, p. 116.

${ }^{88}$ In: Direito Processual Internacional. Rio de Janeiro: Villani Filhos, 1971, p. 43 apud FRANCESCHINI, José Inácio Gonzaga. In: A lei e o foro de eleiçāo em contratos internacionais. Contratos Internacionais. $2^{a}$ ed., revista e ampliada, Coord. João Grandino Rodas, São Paulo: Revista dos Tribunais, 1995, p. 116.

${ }^{89}$ In: Da Competência Internacional e dos princípios que a informam. Revista de Processo no 50 , Ano XIII, Abril-Junho de 1988, p. 54.
} 
algum outro ponto de contato com o ordenamento jurídico brasileiro que faça surgir o interesse da justiça do Brasil em exercer sua jurisdição sobre a causa. Assim também se posiciona Barbosa Moreira ${ }^{90}$ ao sustentar que os elementos contidos no artigo $88 \mathrm{e}$ também aqueles do artigo 89 do Código de Processo Civil são meramente indicativos e sua numeração não é taxativa, devendo eventuais lacunas da lei serem suprimidas mediante as regras de competência contidas no direito interno as quais também serviriam para firmar a competência internacional da justiça brasileira, bem como por analogia e com base nos princípios gerais do direito. Sustenta o referido autor que há casos em que seria absurdo negar a competência da justiça brasileira pelo simples fato de não ter a hipótese sido contemplada dentre aquelas previstas nos artigos 88 e 89 do Código de Processo Civil (como ocorre, por exemplo, nas causas de jurisdição voluntária), ou ainda, naqueles casos de inexistência de uma Justiça internacionalmente competente para o julgamento do feito, mas que haja alguma vinculação da causa com o Brasi ${ }^{91}$.

\footnotetext{
90 In: Problemas relativos a litígios intemacionais. Revista de Processo no 65, Ano 17, Janeiro-Março de 1992, p. 147-148.

${ }^{91}$ Neste particular, BARBOSA MOREIRA, José Carlos, In: Problemas Relativos à Litígios Intemacionais. Revista de Processon ${ }^{\circ}$ 65, Janeiro-Março de 1992, p. 148, menciona decisão do Tribunal de Justiça do Estado do Rio de Janeiro (Apelação Cível n 34.326, 07.02.1985), na qual a ação foi julgada pela justiça brasileira, pois se esta não o fizesse o autor, cidadão português residente no Brasil, não teria a quem se dirigir para postular a decretação de seu divórcio, tendo em vista que a justiça portuguesa seria incompetente para o julgamento do feito por ser o autor residente no Brasil.
} 
Contudo, ainda que o princípio da efetividade não seja aceito pela totalidade dos doutrinadores, é possível encontrar decisões de variados tribunais pátrios ${ }^{92}$, inclusive do Superior Tribunal de Justiça, nas quais as causas não foram julgadas, por força do princípio da efetividade.

Assim sendo, mesmo eleito o foro brasileiro pelas partes, é possível que, em face do princípio da efetividade e presentes os requisitos caracterizadores do mesmo, seja afastada a atuação do juiz nacional.

\subsection{MERCOSUL}

Importante frisar a existência, no âmbito do Mercosul, do Protocolo de Buenos Aires sobre Jurisdição Internacional em Matéria Contratual Civil e Comercial ${ }^{93}$, o qual tem sua aplicação a todos os contratos internacionais de natureza civil ou comercial celebrados entre particulares com domicílio ou sede social em diferentes Estados-Partes

${ }^{92}$ O Tribunal de Justiça do Estado de Santa Catarina recentemente decidiu que "o exercício da jurisdição depende da efetivação do julgado. Logo, não tem o Estado interesse jurídico no seu exercício em causa cuja sentença não possa executar, sobretudo quando as duas empresas estrangeiras, sem filial no Brasil, elegem o foro de terceiro país para deslindar a contenda", conforme ementa a seguir transcrita: "Competência intemacional. Transporte marítimo. Negócio celebrado no exterior, para cumprimento também no exterior, entre empresas estrangeiras sem filial no Brasil. Foro de eleição de justiça de terceiro país. Incompetência da Justiça Brasileira para processar e julgar ação que tem como causa de pedir perdas e danos decorrentes de arribação de navio a porto brasileiro por força de defeito mecânico que só pode ser utilmente executada no exterior. Ausência de interesse jurídico no exercício da jurisdição. Apelo desprovido." (TJSC, Ap. Cível no 88.060151-3 (41005), São Francisco do Sul, Rel. Des. Eládio Torret Rocha, Câmara Cível Especial, j. 05.03.1997). O Tribunal de Justiça do Estado do Rio de Janeiro (Apelaçāo Civel no 5.097/94, 6ª Câmara Cível, maioria, Rel. Des. Marlan de Moraes Marinho, j. 06.12.1997, in Revista de Direito vol. 24, p. 140-145), ao decidir pela validade de cláusula de eleição de foro alienigena, também utilizou-se do princípio da efetividade, a fim de confirmar a sentença de $1^{\circ} \mathrm{grau}$ que havia julgado extinto o processo, por falta de pressuposto básico de constituição e de desenvolvimento válido do mesmo (no caso a jurisdição brasileira). Conforme consta do voto do Desembargador Mello Serra, seria indispensável "examinar a questão do ponto de vista do Princípio da Efetividade, que segundo a doutrina, é o que estabelece a competência intemacional, segundo a possibilidade de ser ou não a sentença, proferida em um país, reconhecida por países estrangeiros. Pois, sendo o Estado uma organização prática, não seria de seu interesse ocupar seus juízes com questōes inúteis, cujas sentenças não poderiam ser executadas. Na espécie, não será necessáno grande senso de observação, para se verificar a clara impossibilidade de serem reconhecidas como válidas as eventuais sentenças de mérito, que poderiam ser proferidas neste processo. É que, a parte alienigena, sobre a qual elas deveriam produzir efeitos, não está sujeita a nossa soberania e, portanto, a nossa jurisdição. Por isso, e porque não participou das lides, por certo, recorrerá ela ao Tribunal de eleição, para ver reconhecido seus direitos, numa incômoda e desprestigiosa litispendência para o nosso Tribunal." O Superior Tribunal de Justiça, utilizando-se dos ensinamentos de José Inácio Botelho de Mesquita, confirmou a decisão recorrida que havia juigado extinto o processo, em face da incompetência da Justiça Brasileira para julgamento de feito não incluído nas hipóteses previstas nos artigos 88 e 89 do Código de Processo Civil Brasileiro. No caso em tela, decidiu-se que a conexão não é elemento de fixação da competência intemacional brasileira, sob o fundamento de que "admitir-se que a conexão possa levar a que se firme a competência da autoridade judiciária brasileira, para hipóteses não cogitadas nos artigos 88 e 89 do CPC, poderá levar a uma alargamento excessivo daquela, colocando em risco o princípio da efetividade que domina a matéria," conforme ementa a seguir transcrita: "Competência intemacional. Causas conexas. A competência da autoridade judiciária brasileira fimase quando verificada alguma das hipóteses previstas nos artigos 88 e 89 do CPC. O direito brasileiro não elegeu a conexão como critério de fixaçāo da competência internacional que não se promogará, por conseguinte, em função dela." (STJ, Terceira Turma, REsp 2.170 - SP, Rel. Min. Eduardo Ribeiro, j. 07.08.1990, in RSTJ, Brasília, 2 (12): 261-437, agosto 1990)

${ }_{93} \mathrm{O}$ Protocolo de Buenos Aires foi promulgado no Brasil pelo Decreto $\mathrm{n}^{\circ} 2.095$, de 17 de Dezembro de 1996, tendo entrado em vigor na data de sua publicação em 18 de Dezembro de 1996. 
do Tratado de Assunção ou quando pelo menos uma das partes do contrato tenha seu domicílio ou sede social em um Estado-Parte do Tratado de Assunção e, além disso, tenha sido feito um acordo de eleição de foro em favor de um juiz de um Estado-Parte e exista uma conexão razoável segundo as normas de jurisdição previstas no referido Protocolo. Exclui-se, no entanto, do âmbito de aplicação do mesmo algumas relações jurídicas, tais como aquelas entre os falidos e seus credores e demais procedimentos análogos, especialmente as concordatas; os contratos de seguridade social, administrativos, de trabalho, de venda ao consumidor, de transporte, de seguro, bem como aqueles relativos a direitos reais além da matéria tratada em acordos no âmbito do direito de família e das sucessóes ${ }^{94}$.

Eduardo Tellechea Bergman ${ }^{95}$ ressalta como normas que tiveram especial relevância para elaboração do referido Protocolo de Buenos Aires, o Tratado de Montevideo de Direito Civil Internacional de 1940, vigente entre os países do Uruguai, Argentina e Paraguai, bem como as normas contidas no Código de Bustamante, na Convenção Interamericana sobre Competência na Esfera Internacional para a Eficácia Extraterritorial de Sentenças Estrangeiras (CIDIP III de La Paz, Bolívia, 1984), na Convenção Européia de Bruxelas de 27.09.1968 ${ }^{96}$ e na Convenção Européia de Lugano de 16.09.1988 ${ }^{97}$. Além destas, Sara L. Feldstein de Cárdenas ${ }^{98}$ menciona, como fontes normativas para a elaboraçăo do Protocolo de Buenos Aires, a Convenção Interamericana sobre Domicílio das Pessoas Físicas celebrada em Montevideo no ano de 1979 e o Tratado de Direito Comercial Terrestre Internacional celebrado em Montevideo no ano de 1939/1940.

O Protocolo de Buenos Aires trata não somente da eleição de jurisdição, mas também, na ausência de acordo expresso acerca do tema, das hipóteses de jurisdição subsidiária. Em face do objeto do presente trabalho, esclarecemos que este será limitado à análise das normas contidas no Protocolo de Buenos Aires que tratam da eleição de foro tão somente.

\footnotetext{
${ }^{94}$ Artigo 2 do Protocolo de Buenos Aires.

${ }^{95}$ In: Un Marco Jurídico al Servicio de La Integración. Las Regulaciones del Mercosur sobre Jurisdicción Internacional. Contratos Internacionais e direito econômico no Mercosul após o término do período de transição. Coordenador Paulo Borba Casella, com a colaboração de Nádia de Araújo, Umberto Celli e Ricardo Th. Da Cunha. São Paulo: LTr, 1996, p. 48-74.

${ }_{96}$ A Convenção de Bruxelas foi subscrita em 27.09.1968 pela Bélgica, Alemanha, França, Itália, Luxemburgo e Holanda, tendo entrado em vigor em 01.02.1973. Conforme ressalta CARDENÁS, Sara L. Feldstein. In: Jurisdiccion Internacional en materia contractual, Abeledo Perrot: Buenos Aires, 1995, p. 120, o texto original sofreu inúmeras alterações em face dos sucessivos convênios de adesão de novos Estados membros da Comunidade Européia, tendo a Convenção sido ratificada pela Dinamarca, Irlanda e Reino Unido em 1978, pela Grécia em 1982 e pela Espanha e Portugal em 1989.

97 A Convenção de Lugano foi firmada em 16.09.1988 pelos Estados membros da Comunidade Européia e da EFTA (Associação Européia de Comércio Livre) que abrange a Áustria, Finlândia, Islândia, Noruega, Suécia e Suiça. Vigora na Holanda, França, Suiça, Portugal e Itália desde o ano de 1992 e na Suécia desde 01.01.1993.

${ }^{98}$ In: Jurisdicción Internacional em Materia Contractual. El Sistema Juridico en el Mercosur. Buenos Aires: Abeledo-Perrot. 1995.
} 
O artigo 4 disciplina a eleição de foro nos contratos civis ou comerciais no âmbito do Mercosul, sustentando que "nos conflitos que decorram dos contratos internacionais em matéria civil ou comercial seráo competentes os tribunais do Estado-Parte em cuja jurisdição os contratantes tenham acordado submeter-se por escrito, sempre que tal ajuste não tenha sido obtido de forma abusiva."

Verifica-se que, para a validade da cláusula de eleição de foro no âmbito do Mercosul, é exigido que a mesma seja escrita e não tenha sido obtida de forma abusiva, o que ocorreria na hipótese de eventual contrato de adesão firmado entre as partes contratantes. Neste particular, a Convenção de Bruxelas, por exemplo, é mais flexível, pois admite que a cláusula seja verbalmente pactuada pelas partes, desde que haja a posterior confirmação por escrito ou, ainda, seja convencionada em consonância com os usos comerciais ${ }^{99}$.

Segundo o artigo 5, item 2 , a validade e os efeitos da eleição de foro são regidos, também, pelo direito dos Estados-Partes que teriam jurisdição de conformidade com o disposto no Protocolo de Buenos Aires, tendo em vista que é o direito interno do país cujo foro foi eleito pelas partes que indicará o órgão julgador competente, dentro de sua organização judiciária, para solucionar a controvérsia.

Em relação à validade da cláusula e considerando que o artigo 1 , " $b$ " exige que haja uma conexão razoável desta com as normas de jurisdição do Protocolo de Buenos Aires, Sara L. Feldstein de Cárdenas ${ }^{100}$ sustenta que as cláusulas de eleição de foro em contratos internacionais submetidos às regras do Protocolo somente serão válidas caso tenham uma vinculação, não fraudulenta, com algum dos critérios selecionados pelo Protocolo, tais como o lugar do cumprimento do contrato, o lugar do domicílio, dentre outros.

Assim sendo, se inexistir qualquer tipo de vinculação da cláusula de eleição de foro com os critérios de conexão previstos no Protocolo de Buenos Aires, Sara L. Feldstein de Cárdenas defende que a cláusula é inválida, pois o objetivo do legislador comunitário é justamente evitar, com esta disposição, o forum shopping.

Caso constatada alguma dúvida ou ambigüidade suscitada em relação ao acordo de eleição de jurisdição, exige-se, ainda, seja aplicado o direito mais favorável no tocante à validade do mesmo. ${ }^{101}$ Neste particular, Beat Walter Rechsteiner ${ }^{102}$ sustenta que "cumpre à jurisprudência dos Estados-Partes do Mercosul determinar quais são os direitos a

\footnotetext{
${ }^{99} \mathrm{Em}$ relação à forma da cláusula de eleição de foro, dispõe o artigo 17, da Convenção de Bruxelas, que "tal convênio atributivo de competência deverá ser celebrado: a) por escrito ou verbalmente com confirmação por escrito; ou b) em uma forma que se ajuste aos hábitos que as partes tiverem estabelecido entre elas; ou c) no comércio internacional, em uma forma conforme os usos que as partes conhecem ou deveriam conhecer e que em dito comércio seja amplamente conhecidos e regularmente observados pelas partes nos contratos do mesmo tipo no setor comercial considerado." 100 In: Jurisdicción Internacional em Materia Contractual. El Sistema Juridico en el Mercosur. Buenos Aires: Abeledo-Perrot. 1995, p. 45-46.

101 Artigo 5, item 3, do Protocolo de Buenos Aires.

102 In: Direito Internacional Privado: teoria e prática. $2^{\text {a }}$ ed. Ampliada e atualizada. São Paulo: Ed. Saraiva, 1998, p.279-280.

${ }^{103}$ Artigo 5, item 1, do Protocolo de Buenos Aires.
} 
serem levados em consideração para definir o direito mais favorável em relação à validade do acordo."

Note-se que a cláusula de eleição de foro não precisa ser pactuada no momento da celebração do contrato, admitindo-se, ainda, que seja acordada durante a vigência do contrato ou uma vez suscitado o litígio ${ }^{103}$. Neste particular, Antônio Corrêa ${ }^{104}$ defende que "a possibilidade de ser instituído foro de eleição deve ocorrer antes de instaurada a instância judicial sob pena de se impor ao órgão jurisdicional a decisão de uma lide em que o convencionamento do julgador diante dos fatos e da lei aplicável seja contrário ao que afirmam as partes."

Percebe-se, portanto, que há legislação específica - Protocolo de Buenos Aires - regulando expressamente a validade das cláusulas de eleição de foro entre partes contratantes originárias de países membros do Mercosul.

Dúvida que surge, no entanto, em relação às cláusulas de eleição de foro inseridas em contratos regulados pelo Protocolo de Buenos Aires, é se o foro eleito é exclusivamente competente para o julgamento da controvérsia ou se o mesmo não obsta o julgamento pela autoridade judiciária do país, cuja competência, de acordo com as suas regras de direito processual, seja concorrente. Note-se que o texto do Protocolo não é claro a respeito deste tema, ao contrário, por exemplo, do artigo $17^{105}$ da Convenção de Bruxelas ${ }^{106}$, e do artigo 5을 da Lei Federal Suíça sobre o Direito Internacional Privado, de 18 de Dezembro de $1987^{107}$, os quais expressamente prevêem que o foro eleito pelas partes é exclusivo.

Beat Walter Rechsteiner ${ }^{108}$ ressalta que este, dentre outros, é um dos problemas verificados em relação ao Protocolo de Buenos Aires, propondo que as lacunas existentes

\footnotetext{
${ }_{104}$ In: Mercosul-Solução de Conflitos pelos Juizes Brasileiros. Porto Alegre: Sergio Antonio Fabris Editor. 1997, p.131.

${ }^{105}$ Dispõe o artigo 17 da Convenção de Bruxelas que "se as partes, quando ao menos uma delas tiver seu domicilio em um Estado contratante, tiverem acordado que um tribunal ou os tribunais de um Estado contratante sejam competentes para conhecer de qualquer litígio que houver surgido ou que puder surgir por ocasiāo de uma determinada relação jurídica, tal tribunal ou tais tribunais serão os únicos competentes. (...)"

106 Para maiores esclarecimentos acerca do disposto na Convenção de Bruxelas, vide o artigo publicado na Revista da Faculdade de Direito da Universidade de Lisboa, de autoria de António Sequeira Ribeiro, Sobre os Pactos de Jurisdição na Convenção de Bruxelas de 1968: Uma breve abordagem ao art. 17, Portugal: Coimbra Editora, 1998.

${ }_{107}$ Vide os comentánios de OVERBECK, Alfred E. Von. In: A eleição de foro segundo a nova lei suiça sobre o Direito Internacional Privado de 18 de Dezembro de 1987. Revista da Faculdade de Direito da UFRGS, v. 12, p. $7-18,1996$. Neste artigo, encontramos comentários acerca do artigo $5^{\circ}$ da Lei Federal Suíça de 18 de Dezembro de 1987, a seguir transcrito: "IV - Eleição de foro. 1. Em matéria patrimonial, as partes podem convencionar sobre o tribunal chamado a resolver um conflito nascido ou a nascer por ocasião de uma relação de direito determinada. A convenção pode ser feita por escrito, por telegrama, telex, fax ou qualquer outro meio de comunicação que permita estabelecer a prova por um texto. Salvo estipulação em contrário, a eleição de foro é exclusivo. 2. A eleição de foro fica sem efeito se ela priva, de forma abusiva, uma das partes da proteção que lhe assegura um foro previsto pelo Direito Suiço. 3. O Tribunal eleito não pode declinar de sua competência: a. Se uma parte é domiciliada, tem sua residência habitual ou um estabelecimento no cantão onde ele tem sede, ou b. Se em virtude da presente lei, o Direito Suiço é aplicável ao litígio."

${ }_{108}$ In: Direito Intemacional Privado: teoria e prática. $2^{\mathrm{a}}$ edição ampliada e atualizada, São Paulo: Saraiva, 1998, p. $280-281$.
} 
no mesmo sejam preenchidas pela lex fori: "Questóes relevantes em relação à eleição de foro em Estados-membros do Mercosul não são reguladas pelo protocolo. Assim, este não diz se o foro eleito é exclusivo, ou seja, se as partes podem ou não ingressar perante um outro juízo que seja internacionalmente competente, apesar de existir uma cláusula de eleição de foro no contrato internacional celebrado por elas. Ademais, o protocolo silencia sobre os pressupostos que sejam necessários para que uma cláusula de eleição de foro possa obrigar os herdeiros e sucessores das partes do contrato. A nosso ver, é exclusivamente a lex fori que deve preencher as lacunas do protocolo. Trata-se, aqui, de questóes relativas aos efeitos da cláusula de eleição de foro. Estas não se restringem apenas a sua validade, o que permitiria levar em consideração o direito mais favorável nos termos do protocolo."

Parece-nos, desta forma, que a controvérsia acabará sendo superada pela interpretação dos tribunais em relação às regras contidas no Protocolo de Buenos Aires. Contudo, até à conclusão deste trabalho, não localizamos quaisquer decisōes acerca do tema que pudessem demonstrar o posicionamento dos tribunais em relação à cláusula de eleição de foro nos contratos internacionais entre partes de países membros do Mercosul, tendo, no entanto, Nadia de Araujo ${ }^{109}$ mencionado que a Carta Rogatória no 8837 , originária do Paraguai, teria sido devolvida pelo Supremo Tribunal Federal, sob a alegação de que uma vez eleito o foro brasileiro, seria impossível a citação da empresa brasileira através da referida Carta Rogatória, pois somente aqui poderia ser acionada, em consonância com o disposto na cláusula pactuada pelas partes contratantes.

De qualquer forma, o tema da exclusividade ou não da cláusula de eleição de foro deverá ser objeto de debate, não somente da doutrina, mas também dos tribunais, a fim de solidificar uma interpretação uniforme do Protocolo de Buenos Aires, o qual não regulou expressamente a matéria, ao contrário, por exemplo, da Convenção de Bruxelas e da Lei Federal Suíça sobre o Direito Internacional Privado, de 18 de Dezembro de 1987.

\section{CONCLUSÃO}

Verifica-se que não são poucas as questões relacionadas à cláusula de eleição de foro em contratos internacionais. Conforme foi constatado, a análise e negociação da cláusula de eleição de foro, juntamente com as demais cláusulas contratuais, é imprescindível, pois, o conteúdo da mesma afeta diretamente a questão da lei aplicável a um contrato, em especial, naqueles ordenamentos jurídicos que não consagraram a autonomia da vontade como elemento de conexão a reger a matéria, como é o caso do direito brasileiro.

Há uma série de limitações existentes no ordenamento jurídico pátrio que poderão acarretar a inobservância do disposto na cláusula de eleição de foro convencionada pelas partes.

${ }^{109}$ A decisão é mencionada na obra Contratos Intemacionais, $2^{2}$ edição, Rio de Janeiro: Renovar, 2000, p. 265. 
Com efeito, estas limitações, no entanto, não são somente legais, como nas hipóteses de competência absoluta previstas no artigo 89 do Código de Processo Civil Brasileiro, mas também decorrem do entendimento dos tribunais pátrios acerca do tema.

Note-se que, tratando-se de hipótese de competência concorrente da justiça brasileira e eleito foro estrangeiro para o julgamento do feito, isto não obsta que a ação seja aqui julgada, afastando-se, assim, o disposto livremente pelas partes no instrumento contratual firmado pelas mesmas.

Desta forma, constata-se que do confronto entre eventual cláusula de eleição de foro alienígena e uma hipótese de competência concorrente da justiça brasileira, os tribunais pátrios têm sustentado que esta deve prevalecer, afastando o que houvera sido prévia e livremente estipulado sobre o assunto. Sem dúvida, este posicionamento jurisprudencial deverá ser considerado quando da negociação de um contrato internacional, em face dos riscos da cláusula de eleição de foro ser desconsiderada pelo juiz estatal brasileiro, sujeitando as partes, ainda, à interpretação e julgamento deste no que tange eventual lei livremente pactuada pelas mesmas.

Verifica-se, portanto, conforme salienta Nadia de Araujo ${ }^{110}$, que "quandoé preciso decidir-se entre a cláusula e a competência, esta última é a preferida" pelos tribunais pátrios, pois estes, nas hipóteses de competência concorrente, não afastam a atuação do juiz nacional, ainda que as partes tenham livremente estipulado, em contrato internacional firmado pelas mesmas, foro diverso para o julgamento da controvérsia.

De qualquer sorte, é mister mencionar que caso a controvérsia seja julgada em foro diverso do que aquele contratualmente estipulado, a parte que eventualmente se julgar prejudicada poderá postular perdas e danos em decorrência do descumprimento de cláusula contratual ou ainda demandar o pagamento de cláusula penal convencionada pelas partes no instrumento contratual. É possível, portanto, discutir a responsabilidade de uma parte contratante por eventuais danos causados a outra, em decorrência da violação da cláusula de eleição de foro pactuada livre e expressamente entre as mesmas.

Por óbvio, a cláusula de eleição de foro nos contratos internacionais não é aleatoriamente determinada, mas pressupõe uma ampla análise dos dispositivos legais dos ordenamentos jurídicos envolvidos, refletindo uma escolha mais favorável para ambas as partes contratantes, inclusive sob o ponto de vista econômico, devendo, portanto, ser observada. Neste sentido, reportamo-nos ao famoso leading case Bremen v. Zapata da Suprema Corte norte-americana, no qual foi sustentada a necessidade de observar o disposto na cláusula de eleição de foro, tendo vista que "the forum clause was a vital part of the agreement, and it would be unrealistic to think that the parties did not conduct their negotiations, including fixing monetary terms, with the consequences of the forum clause selection figuring prominently on their calculations." Desta forma, a inobservância da cláusula por qualquer uma das partes contratantes, por ter reflexos econômicos e importar em análise do contrato de forma diversa pela justiça não eleita previamente pelas partes, pode embasar eventual ação de perdas e danos pelo contratante prejudicado, ou ainda, acarretar o

110 In: Contratos Intemacionais. $2^{\text {a }}$ ed., Rio de Janeiro: Renovar, 2000, p. 286-287. 
pagamento de cláusula penal prevista no instrumento contratual por descumprimento do mesmo.

Assim sendo, embora a cláusula de eleição de foro seja amplamente aceita no direito brasileiro, ressalvadas as limitações abordadas no presente trabalho, verifica-se que o tema é bastante complexo em face das implicações que o mesmo apresenta.

Na negociação de um contrato internacional, é mister, portanto, atentar não somente para as normas dos países com alguma conexão com o contrato, quer, por exemplo, seja o domicilio das partes ou o lugar de celebração ou de execução do contrato, mas também para o posicionamento dos tribunais locais, a fim de constatar a possibilidade de eventual cláusula de eleição de foro ser afastada, acarretando, ainda, a inobservância da cláusula de eleição da lei aplicável ao contrato, caso também pactuada pelas partes e inadmitida no país no qual a controvérsia é julgada. 


\section{Bibliografia}

ALVIM, Arruda. Competência Internacional. Revista de Processo no 7-8, Ano II, Julho-Dezembro de 1977.

ARAUJO, Nadia de. Contratos Internacionais: autonomia da vondade, Mercosule convençōes internacionais. $2^{\mathrm{a}}$ edição, Rio de Janeiro: Renovar, 2000.

- A autonomia da vontade nos contratos internacionais - direito brasileiro e paises do Mercosul: Consideraçóes sobre a necessidade de alterações no Direito Internacional Privado do Bloco. Palestra proferida no Curso de Especialização "O Novo Direito Internacional". Porto Alegre: UFRGS, 1999.

BAPTISTA, Luiz Olavo. Contratos Internacionais. Revista Forense, $\mathrm{n}^{\circ}$ 270, Ano 76, Abril-Junho de 1980.

BARBI, Celso Agrícola. Comentários ao Código de Processo Civil, volume 1. 10? ed. rev. e amp. Rio de Janeiro: Forense, 1998.

BARBOSA MOREIRA, José Carlos. Problemas relativos a litígios internacionais. Revista de Processo no 65, Ano 17, Janeiro-Março de 1992.

BASSO, Maristela. Contratos Internacionais do Comércio. Porto Alegre: Livraria do Advogado, 1998.

BERGMAN, Eduardo Tellechea. Un Marco Jurídico al Servicio de La Integración. Las Regulaciones del Mercosur sobre Jurisdicción Internacional. Contratos Internacionais e direito econômico no Mercosul_após o término do período de transição. Coordenador Paulo Borba Casella, com a colaboraçáo de Nádia de Araújo, Umberto Celli e Ricardo Th. Da Cunha. São Paulo: LTr, 1996.

BORN, Gary B. International Civil Litigation in United States Courts. Third Edition, Den Haag: Kluwer Law International, 1996.

CALIXTO, Negi. Contratos Internacionais e Ordem Pública. Revista dos Tribunais, no 701, Ano 83, Março de 1994.

CÁRDENAS, Sara L. Feldstein de. Jurisdiccion Internacional em materia contractual. Buenos Aires: Abeledo-Perrot, 1995. 
CARMONA, Carlos Alberto. Arbitragem e Processo: Um comentárioà Lei 9.307/ 96. São Paulo: Malheiros, 1998.

CARNEIRO, Athos Gusmão. Jurisdição e competência. 9ª edição, São Paulo: Saraiva, 1999.

CASTRO, Amilcar de. Direito Internacional Privado. $5^{\mathbf{a}}$ ed. aum. e atualizada. Rio de Janeiro: Forense, 1995.

CORRÊA, Antonio. Mercosul: Solução de conflitos pelos juízes brasileiros. Porto Alegre: Sergio Antonio Fabris Editor, 1997.

DINIZ, Maria Helena. Lei de Introdução ao Código Civil Brasileiro Interpretada. 5ª ed. atualizada. São Paulo: Saraiva, 1999.

DOLINGER, Jacob. A evolução da Ordem Pública no Direito Internacional Privado. Rio de Janeiro, 1979.

ESPÍNOLA, Eduardo e Eduardo Espínola Filho. A Lei de Introdução ao Código Civil Brasileiro. $3^{\text {a }}$ ed., Rio de Janeiro: Renovar, 1999.

FAWSETT, J.J. Declining Jurisdiction in Private International Law: Reports to the XIVth Congress of the International Academy of Comparative Law. Oxford: Clarendon Press, 1995.

FRANCESCHINI, José Inácio Gonzaga. A Lei e o Foro de Eleição em Tema de Contratos Internacionais. Contratos Internacionais, $2^{\mathbf{a}}$ edição, rev. e amp. Coordenador João Grandino Rodas, São Paulo: Editora Revista dos Tribunais, 1995.

GOLDSMITH, Jack L. International Dispute Resolution: The regulation of forum selection. Fourteenth Sokol Colloquium. Irvinton, New York: Transnational Publishers, Inc., 1997.

HUCK, Hermes Macedo. Sentença Estrangeira e Lex Mercatoria: Horizontes e fronteiras do comércio internacional. São Paulo: Saraiva, 1994.

LIMA, Francisco Gérson Marques de. Lei de Introdução ao Código Civile Aplicação do Direito do Trabalho. São Paulo: Malheiros, 1996.

LOUREIRO FILHO, Lair da Silva. Lei de Introdução ao Código Civil Interpretada: Jurisprudência e Bibliografia. São Paulo: Editora Juarez de Oliveira, 2000. 
MAGALHÃES, José Carlos de. Competência Internacional do Juiz Brasileiro e Denegação da Justiça. Revista dos Tribunais, no 630, Ano 77, Abril de 1988.

MELLO, Marcelo Oliveira e Carlos Cesar Borromeu de Andrade. A Arbitragem nos Contratos Comerciais e Petrolíferos Internacionais. A Arbitragem na era da globalização. Coordenador José Maria Rossani Garcez. Rio de Janeiro: Forense, 1997.

MESQUITA, José Ignácio Botelho de. Da Competência Internacional e dos princípios que a informam. Revista de Processo no 50, Ano XII, Abril-Junho de 1988.

MIRANDA, Pontes de. Comentários ao Código de Processo Civil, Tomo II, Rio de Janeiro: Forense, 1973.

NYGH, Peter. Choice of Forum and Law in International Commercial Arbitration. Forum Internationale, no 24, Junho de 1997. Holanda: Kluwer Law International, 1997.

OCTAVIO, Rodrigo. Manual do Código Civil, volume 1, parte segunda, Direito Internacional Privado, arts. 8 a 21, Rio de Janeiro: Livraria Jacintho, 1932.

OVERBECK, Alfred E. Von. A Eleição de Foro segundo a Nova Lei Suíça sobre o Direito Internacional Privado de 18 de Dezembro de 1987. Revista da Faculdade de Direito da Universidade Federal do Rio Grande do Sul, volume 12, Porto Alegre: UFRGS, 1996.

PEREIRA, Luís Cezar Ramos. A competência internacional da autoridade judiciária brasileira. Revista dos Tribunais, no 586, Ano 73, Agosto de 1984.

A Litispendência Internacional no Direito Brasileiro. Revista dos Tribunais, nº 711, Ano 84, Janeiro de 1995.

RECHSTEINER, Beat Walter. Arbitragem Privada Internacional no Brasil: Depois da nova Lei 9.307, de 23.09.1996. São Paulo: Editora Revista dos Tribunais, 1997.

—Direito Internacional Privado: Teoria e Prática. São Paulo: Saraiva, 1998.

RIBEIRO, António Sequeira. Sobre os Pactos de Jurisdição na Convenção de Bruxelas de 1968: Uma breve abordagem ao art. 17. Revista da Faculdade de Direito da Universidade de Lisboa, Portugal: Coimbra Editora, 1998.

ROVIRA, Suzan Lee Zaragoza de. Estudo comparativo sobre os contratos internacionais: Aspectos doutrinários e práticos. Contratos Internacionais, $2^{\mathrm{a}}$ edição, 
rev. e amp. Coordenador João Grandino Rodas, São Paulo: Editora Revista dos Tribunais, 1995.

RUSSOMANO, Mozart Victor. Comentários à Consolidação das Leis do Trabalho. Volume IV, 7ª edição, Rio de Janeiro: Editor José Konfino, 1966.

SANTOS, Moacir Amaral. Primeiras Linhas de Direito Processual Civil: Adaptadas ao Novo Código de Processo Civil. São Paulo: Saraiva, 1982-1983.

SILVA, Luiz Alberto de Souza. Direito Internacional Privado (Lei de Introdução ao Código Civil). Rio de Janeiro: Lumen Juris, 2000.

SILVA, Ovídio A. Baptista. Comentários ao Código de Processo Civil, v. 1: Do processo de conhecimento, arts. $1^{\circ}$ ao 100 . São Paulo: Editora Revista dos Tribunais, 2000.

SÜSSEKIND, Arnaldo et al. Instituições de direito do trabalho. 16 ${ }^{\mathbf{a}}$ edição, São Paulo: Ltr, 1996.

STRENGER, Irineu. Contratos Internacionais do Comércio. São Paulo: Editora LTr, 3ํe edição revista e ampliada, 1998.

TEIXEIRA, Sálvio de Figueiredo. A arbitragem no Sistema Jurídico Brasileiro. $A$ arbitragem na era da globalização. Coordenador José Maria Rossani Garcez, Rio de Janeiro: Forense, 1997

TENÓRIO, Oscar. Direito Internacional Privado. $11^{\mathrm{a}}$ edição, revista e atualizada. Rio de Janeiro: Freitas Bastos, 1976.

VAGTS, Detlev F. Transnational Business Problems. University casebook series. $2^{\mathrm{a}}$ ed., Nova York: Foundation Press, 1998.

VALADÃO, Haroldo. O Contrato Internacional. Revista Forense, no 269, Ano 76, Janeiro-Março de 1980.

WALD, Arnoldo. Validade das Convenções sobre foro do contrato. Estudose pareceres de Direito Comercial. São Paulo: Revista dos Tribunais, 1972. 